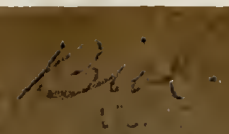

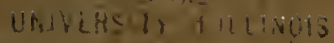

The Museum

of the

Brooklyn Institute of Arts and Sciences.

MEMOIRS OF NATURAL, SOIENOES.

VoL. I. No. 1.

\title{
MEDUSA OF THE BAHAMAS
}

ALERED GOLDSBOROUGH MAYER.

WITH SEVEN PLATES.

APRIL, 1904.

$81020 \%$ 
. 


\section{Digitized by the Internet Archive in 2016 with funding from \\ University of Illinois Urbana-Champaign}




$$
\begin{gathered}
\text { The Museum } \\
\text { of the }
\end{gathered}
$$

Brooklyn Institute of Arts and Sciences.

MEMOIRS OF NATURAL SCIENOES.

VOL. I. No. 1.

\title{
MEDUSA OF THE BAHAMAS
}

BY

\begin{abstract}
ALFRED GOLDSBOROUGH MAYER.
\end{abstract}
WITH SEVEN PLATES.

APRIL, 1904.

BROOKLYN :

Eagle Job Printing Department.

1904. 


\title{
MEDUSAE OF THE BAHAMAS
}

BY

\author{
ALFRED GOLDSBOROUGH MAYER.
}

\section{ALPHABETIOAL LIST OF SPEOIES.}

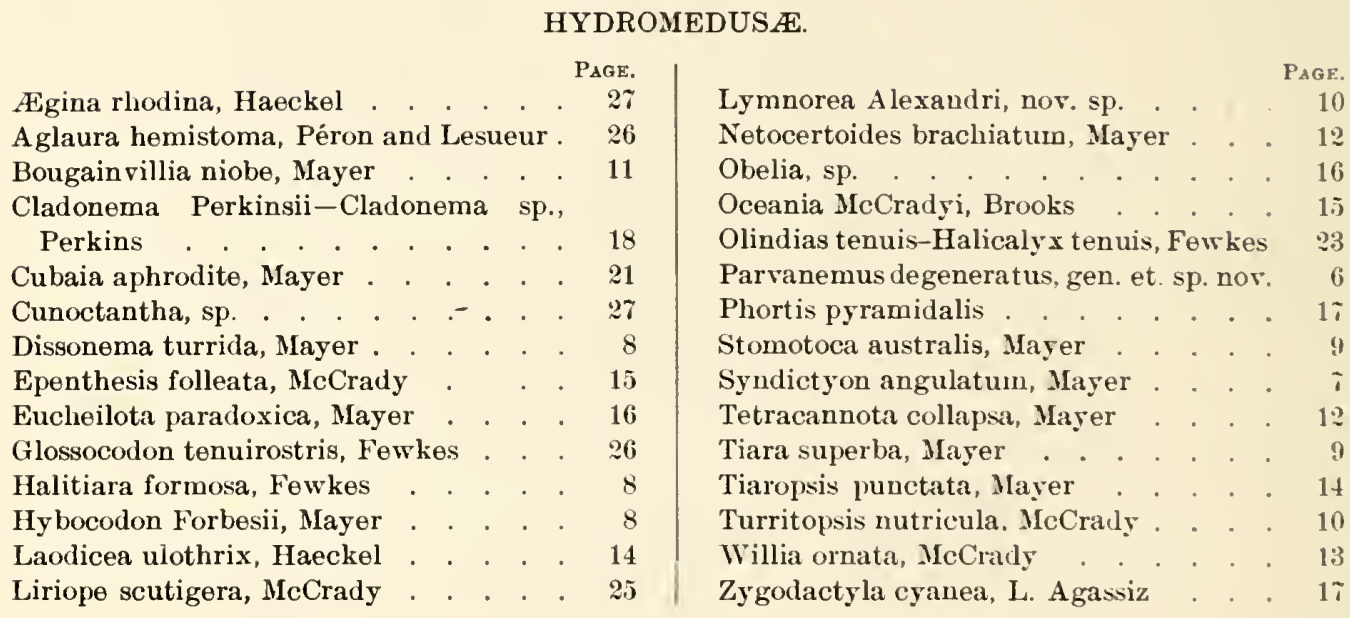

\section{SCYPHOMEDUSÆ.}

Aurelia habanensis, Mayer _. . . . 30 | Nausithoë punctata, Kölliker . . . 30

Cassiopea frondosa, Lamarck . . . . $30 \quad$ Tamoya haplonema, F. Müller . . . . 2.

Linerges mercurius, Haeckel . . . . 30 | “Tamoya punctata," Fewkes . . . . 2s

\section{SIPHONOPHOR E.}

Abyla pentagona, Eschscholtz . . . . 30 Porpita Linueana, Lesson . . . . . . 30

Abyla quincunx, Chun . . . . . . . $30 \quad$ Spharonectes gracilis, Haeckel . . . . 30

Diphyopsis campanulifera, Cliun . . . 30 Velella mutica, Bose . . . . . . . 30

Physalia pelagica, Bosc . . . . . . 30

\section{CTENOPHOR E.}




\section{INTRODUCTION.}

The following observations were made while the writer was in charge of a scientific expedition to the Bahamas under the direction of the Museum of the Brooklyn Institute of Arts and Sciences. The report has received the benefit of valuable suggestions from Professor Charles B. Davenport.

The studies were made in the period extending from June 4-July 27, 1903, and numerous surface hauls were made under most favorable conditions for working.

The medusa-fauna of the Bahamas is poor in comparison with that of the Tortugas, Florida. For example, the writer secured ninety species of Hydromedusæ, Scyphomedusæ, Siphonophoræ and Ctenophoræ at the Tortugas, while only forty-three species were found at the Bahamas.

What is more interesting, the relative abundance of specific forms is quite different in the two regions. Thus the three commonest species at the Tortugas are Pseudoclytia pentata, Halitiara formosa, and Turritopsis nutricula; yet the first was not found at the Bahamas, while the two others were rare. On the other hand one of the commonest medusæ of the Bahama Banks, a new species of Lymnorea, has never been seen at the Tortugas, and species of Netocertoides, Olindias, and Cubaia are abundant on the borders of the Bahama Banks, but very rare at the Tortugas.

Altogether, of 43 Bahama medusie, 23 are about equally abundant at the Tortugas, and 13 of these are either Trachylina forms or Siphonophoræ, which are widely distributed over the Tropical Atlantic. 16 are more abundant at the Bahamas than at the Tortugas, while 4 are more abundant at the Tortugas. 5 medusæ are known only from the Bahamas, and 2 of these are locally abundant.

These considerable differences in the medusa-fauna of two regions upon the same latitude, and being only about 300 miles apart, are co-ordinated with differences in local conditions. For example, the Tortugas lie to leeward of the Gulf Stream, and the rich pelagic life of the great current is constantly driven upon their shores; while the Bahamas lie to windward of the stream,

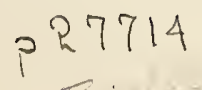


and their local fauna is not reinforced by creatures characteristic of the current. It is interesting to observe, however, that at the Tortugas we find more than a mere concentration of individuals, for a number of characteristic species appear to be confined to this region alone.

Moreover, at the Tortugas we have a small land mass surrounded by pure, deep ocean water, while at the Bahamas we find vast areas of shallow Hats, covered mainly with coralline nud. These great banks of the Bahamas are veritable submarine deserts, covered only with a sparse growth of coralline, algre, and with lere and there a cluster of reef-corals and gorgonians.

It is remarkable, also, that the water over these shallow banks is almost as deficient in life as is the desert bottom itself. Almost no Sagittre, Salpre or Crustacea being found, and among Medusa only Olindias, Cubaia, and Lymnorea are abundant.

Indeed, the water over the banks is usually charged with a flocculent mass of silt, which readily adheres to pelagic animals, and appears to be rapidly fatal to them. Only in this manner can we account for the porerty of pelagic life over the Bahama banks, for the deep-water regions of the Bahamas, such as the Tongue of the Ocean or the area to the eastward of Great Abaco Island, are rich in pelagic animals, which appear to be free from sit and in excellent condition. The water from the deep areas must, however, often be driven over the shallow banks and its life destroyed.

The coral reefs of the Bahamas are richer in species than are those of the Tortugas. They are best developed along the windward edges of the banks, the richest single reef being probably that which extends along almost the entire eastern shore of the Andros Islands, about one mile out from the beach. On the other hand fewer species of marine invertebrates and fishes are found among the Bahama reefs than among those of the Tortugas. The actual area occupied by corals is insignificant in comparison witl the great extent of barren flats around tliem.

In general it appears that while the Tortugas fauna is recruited from the pelagic life of the Gulf Stream, and from the drift eaused by prevailing winds, the Bahama fauna is depleted by the same winds, and is poor in those creatures which are mainly dependent upon great currents for their distribution.

Morphology, etc. A unique opportunity was afforded for the study of the post-embryonic development of Cubaia, and Olindias, and it appears that 
Gonionemus, Cubaia, Vallentinia, Olindioides and Olindias are closely related genera, which may be grouped into one family, the Olindiadx.* The marginal (velar) tentacles of Cubaia and Olindias are secondary and arise quite late in ontogeny. The distinguishing feature of the Olindiadse is the development of a pad-like cluster of modified nematocyst cells upon the aboral side, near the distal extremity, of each and all of the primitive tentacles. These pad-like expansions may serve as adhesive disks or organs of temporary attachment.

A study was also made of the plienomenon of asexual budding in medusæ. One of the most interesting examples is afforded by Eucheilota paradoxica, which is the only Leptomedusa known that produces an asexual generation of medusæ by a direct process of budding. These daughter medusæ are derived from both entoderm and ectoderm of the gonad of the parent (Fig. 65, Plate VII).

We have, therefore, a graded series of phenomena in the asexual production of medusa buds by hydromedusæ. In forms where the ectoderm and entoderm are both thin-layered and of about equal thickness, such as in the Sarsiadae and E. paradoxica, botl entoderm and ectoderm take an equal share in the formation of the bud. In forms such as Rathkea octopunctata and Lizzia Clapereidei, according to Clıun,1895, a different condition is observed, for the medusa buds are formed entirely within the ectoderm of the parent. although the gastro-vascular cavity of the bud finally acquires a connection with that of the parent; the entoderm of the bud becoming continuous with that of the parent manubrium.

In Bougainvillia niobe from the Bahamas, however, the ectoderm is very thick, and the budding medusæ are developed within it alone; the entoderm remaining inert and passive during the growtl of the bud, and no connection ever being established between the gastro-vascular cavities of the bud and the parent. (See Figs. 15-15c, Plate II.) This result may be regarded as due to a gradual process favored by the thickness of the ectoderm, which prevented the deep-lying entoderm from taking an equal share in the formation of the bud, until finally, as in $B$. niobe, it remains passive throughout the period of the formation of the bud. Medusx produced from ectoderm alone may, therefore, be phylogenetically lomologous with medusæ produced bv 
the more primitice and universal co-operation of both ectoderm and entuderm.

New species. Two new species were established, Lymnorea Alexandri, named in honor of the author's constant friend, Alexander Agassiz. It is the most abundant medusa of the Bahama Banks throughout the summer.

The other new form has been named Parranemus degeneratus, and is the most degenerate free-swimming hydromedusa yet described. It lacks tentacles, sense organs, and peripheral rascular system. It swims, howerer, with great activity, but is short-lived. In this form nature appears to hare performed Loeb's experiment, in which, as is well known, he cut away the rim of the bell, depriving the medusa of tentacles and sense organs. Yet the bell still contracted rhythmically when placed in a solution having the same osmotic pressure as sea water, but having no calcium or potassium ions.

Murbach, 1903; Amer. Journ. Physiology, X, p. 201, has shown, lowerer. that in Gonionemus the marginal otocysts lave nothing to do with the maintenance of equilibrium, but that it is probable "that muscular sensation (largely in the velum) is the seat of static function in Gonionemus and in hydromedusæ." It is interesting to observe that the relum of Parranemus is exceptionally large and provided with powerful muscles. Such "muscular sensation" is not always found in the relum, howerer, for in Rhacostoma dispar the bell opening is much reduced and the medusa is propelled by the movements of its widely open mouth. Bull. Mus. Comp. Zoöl. at Harrard Coll., Vol. XXXVII, p. 61, 1900.

\section{DESCRIPTION OF SPECIES.}

For the sake of completeness we present a brief deseription of all species of Hydromedusa known from the Bahamas.

The classification is essentially that of Hacckel.

\section{HYDROMEDUSA.}

Parvanemus degeneratus, gen. et. sp. nov.

Fig. 22, Plate $I I I$.

Generie Characters: Parvanemus: Codonidar without tentacles, radial canals, or circular vessel. 
Specific Characters: The bell is thin-walled, about $0.75 \mathrm{~mm}$. high and $0.3 \mathrm{~mm}$. in diameter. The bell-walls are quite rigid and the velum powerfui and well developed. There are neither tentacles, radial canals, circular vessel, nor marginal sense organs. The manubrium is spindle shaped and about one-third as long as the bell-height. The fluids within the stomachcavity are maintained in rapid motion apparently through the action of cilia. Near the aboral end of the bell there is a deep conical cicatrice which evidently marks the place of last connection between the medusa and its hydroid stock. The bell is translucent and milky in color while the manubrium is cream colored. Only five specimens, all males, were found in Nassau Harbor, Bahamas, on the nights of July 18-19. They swann actively in ares of circles, but all died early in the morning although maintained in large glass dishes filled with pure sea-water. They appeared to be mature, for sperm was discharged constantly from the sides of the manubrium.

This is the only free swimming hydromedusa, yet described, that lacks all traces of tentacles, radial canals, and marginal sense organs. It is even more degenerate than the medusæ of Amalthæa and Pennaria, and may be compared with Eucopella (R. von Lendenfeld, 1883; Zeit. für Wissen. Zoöl., Bd. 38, p. 497), and Agastra (C. Hartlaub, Wissen. Meeresuntersuch. Biologish. Anstalt auf Helgoland, neu folge, Bd. 2, Heft 1, Abt. 2, p. 504, Taf. XXII, Fig. 5, 8-10). In these remarkable medusæ we find neither manubrium nor marginal tentacles. There are, however, eight otocysts, and the radial and circular vessels are well developed.

\section{Syndictyon angulatum, MAYER.}

Fig. 6, Plate $I$.

MaYer, 1900 ; Bull. Mus. Comp. Zoöl. at Harvard Coll., Vol. XXXVII, p. 5, Figs. 6-8. Pl. 3.

The bell is $3 \mathrm{~mm}$. high; half egg-shaped, with moderately thick walls, and becomes almost square in cross section when contracted. There are four slender tentacles with fairly thick spindle-shaped ends. These tentacles are each about as long as the bell height, and their distal halves are armed with nematocysts. The basal bulbs of the tentacles are not very large and each one bears an ocellus formed by a cup-like invagination of ectodermal cells. The velum is large, and the radial canals and circular vessel are of fine calibre. The manubrium is spindle-shaped with a narrow tubular cesophagus, 
and without an aboral projection. It is about two-thirds as long as the height of the bell-carity. The entoderm of the tentacle-bulbs and manubrium is robin-egg blue, while the ocelli are deep brown, almost black. All other parts are hyaline. This medusa is abundant in the Tongue of the Ocean in June and July, and was found at Turks Islands in January.

\section{Hybocodon Forbesii, MaYеR.}

Fig. 13, Plate II.

Mayer, A. G., 1894; Bull. Mus. Comp. Zoöl. at Harvard Coll., Vol. XXV, p. 236, Pl. 1, Fig. 1.

Bell higher than a hemisphere. About $2 \mathrm{~mm}$. high. Bell walls thin and transparent. Three rudimentary and one well developed tentacle; the latter $2 \mathrm{~mm}$. long with its distal end swollen, and studded thickly with nematocysts. Velum rudimentary. Entoderm of namubrium bright yellow. That of the distal end of the long tentacle yellow and red. Nassau Harbor, Baha mas. Spring montlis.

Dissonema turrida, MAYER.

Fig. 10, Plate II.

Mayer, A. G., 1900 ; Bull. Mus. Comp. Zoöl. at Harvard Coll., Vol. XXXVII, p. 44, Pl. 2, rigs. 3,4 .

Bell pyriform, $4 \mathrm{~mm}$. high, with a hollow apical projection. Two large, hollow, tentacles, each about $12 \mathrm{~mm}$. long. Fourteen short slender marginal cirri. Sixteen octodermal ocelli, one on the onter side of the base of each tentacle and cirrus. Manubrium urn-shaped, with four crenulated lips, which project beyond the relar opening. Fonr broad radial canals with four large sac-like gonads on their proximal latves. Ora large and prominent. Entoderm of manubrinm and tentacles delicate green. Gonads and vascular canals delicate pink. Ocelli red. Common throughout summer at Bahamas, and off Florida coast.

\section{Halitiara formosa, FEพ к.s.}

Fig s, Plate $I$.

Fewkes, J. W., 1882; Bull. Muıs. Comp. Zoöl. at Harrard Coll., Vol. IX. p. 2:เs, Pl. 4. Fig. 2.

Bell pyriform, $3 \mathrm{~mm}$. high, with solid apical projection. four long radially situated tentacles, and 24-35 short tentacles witl tapering bases. No ocelli. Velmu well deroloped. Fom straight narrow radial tubes. Manu- 
brimm lyriform. Month a simple round opening; no prominent lips. Entoder'm of manubrium and tentacle bases green in females, light brown in males.

Common at Tortugas; rare in Bahamas. An identical, or very closely allied, form found in the Fiji Islands.

\section{Stomotoca australis, MAYER.}

Fig. 9, Plate $I$.

Mayer, A. G., 1900; Bull. Mus. Comp. Zoöl. at Uarvard Coll., Vol. XXXVII, p. 32, Pl. 1, Fig. 2.

Bell $2.5 \mathrm{~mm}$. high, with solid conical, apical projection, bell-walls thin. Two large diametrically opposed tentacles at bases of two of the radial canals. Two rudimentary tentacle-bulbs at bases of the other two radial canals. Eight ectodermal ocelli, four on outer sides of the tentacle bulbs and four in intermediate positions $45^{\circ}$ from tentacle bulbs. Tentacle bulbs hollow. Velum well developed. Radial canals broad and smooth-edged. Manubrium urn-shaped with four prominent lips. Gonads in complexly folded radially situated regions at upper part of sides of manubrium. Manubrium and tentacle-bulbs greenish yellow, ectodermal core of manubrium and ocelli orange. Common at 'Tortugas, Florida; not so abundant at the Bahamas.

\section{Tiara superba, MAYER.}

Fig. 11, Plate $I 1$.

MaYer, A. G., 1900; Bull. Mus. Comp. Zoäl. at Harvard Coll., Vol. XXXVII, p. 34. P1. 16. Fig. 39.

Bell $5 \mathrm{~mm}$. high; pyriform with short apical projection, and thin walls. Four long, hollow, tapering, and twelve rudimentary tentacles; each with bright red ectodermal ocellus on outer side of tentacle-bulbs. Radial and eircular vessels broad and smooth-edged. Velum well developed. Manubrium urn-shaped, about two-thirds as long as the height of the bell-cavity, with complexly fluted lips. Four gonads in radially situated folded regions on the proximal parts of the manubrium. Four radial mesenteries bind the manubrium to the walls of the radial canals. Entoderm of manubrium and tentacles rose-pink. Core of the manubrium emerald-green. Gelatinous substance of bell delicate pink. Common at Tortugas, Florida; found occasionally at Bahamas, Andros Island, Tongue of the Ocean, Nassau Harbor in June and July. 


\section{Turritopsis nutricula, McС́ану.}

McCrady, J., 1857; Gymn. Charleston Harbor, p. 25, Pls. IV, V, VIII, Fig. 1.

Modeeria multitentacula, Fewres, J. W. 1831; Bull. Mus. Comp. Zuöl. at Hurvard Coll.. Vol. VIII, p. 149, Pl. III, Figs. 7-9.

Brooks, W. K., 1886; Mem. Boston Soc. Nat. Hist., Vol. III, p. 388, Pl. 37.

Bell $4 \mathrm{~mm}$. ligh. Pear-shaped, with thin walls. 40-50 marginal tentacles, each with an ocellus on the outer side near the basal bulb. Four narrow radial canals. Manubrium wide, flask-shaped and one-half as long as the depth of bell carity. Proximal part of manubrium contains large vacuolated cells, through the midst of which the four radial canals extend into the gastric portion of the manubrium. Mouth at end of a short crlindrical tube, and surrounded by four radially-situated nematocyst-bearing knobs. Gonads within the manubrium. Entoderm of manubrium dull yellow streaked with brownish orange. Ocelli of tentacle bulbs brown or orange. The hydroid, discovered by Brooks, is Dendroclava. Medusa common from Cuba to Newport, Rhode Island. Rare at the Bahamas in summer.

Lymnorea Alexandri, sp. nov.

Figs. 1-5a, Plate 1 .

Named in honor of Alexander Agassiz. Bell 4 mu. high, 3 mm. broad, with vertical sides, flat top and thin walls. Thirty-two slender tentacles with tightly coiled ends and large basal bulbs. A black ectodermal oecellus lies npon the onter side of each tentacle-bulb. The relum is well-dereloped. The four radial canals are straight and slender but slightly swollen in the midregions of their lengths, where their inner sides are lined with gland-cells. (Fig. $5^{\mathrm{a}}$, Plate I.)

'The manubrium is flask-shaped and about one-half as long as the depth of the bell-cavity. 'The distal part of the manubrim aljacent to the points of entrance of the four radial canals is composed of highly vacuolated cells. 'The mid region of the manubrinm is cruciform in cross section and the mature genital products are found in the ectoderm. The month is at the extremity of a short neck, and is surrounded by four oral tentacles, each of which branches dichotomously three tinnes, and temminates in eight nentatocyst-bearing knobs, making in all thirty-two of these knobs surrounding the month. The entoderm of the mamubrium and tentadeloulbs is dull, fleshcolored pink. In the youngest medusa seen the bell was 0.6 mm. in dianeter, and hat only tome oral tentacle knobs, four matrinal tentacles and four rudi- 
mentary tentacle-bulbs. This is one of the most abundant medusæ at the Bahamas in summer.

\section{Bougainvillia Niobe, MAYER.}

Figs. 14-15c, Plate II.

MAYeR, A. G., 1894 ; Bull. Mus. Comp. Zoöl. at Harvard Coll., Vol. XXV, p. 236, Pl. I, Fig. 2; Ibid. Vol. XXXVII, p. 42.

Adult Medusa, Fig. 14. Bell $6.75 \mathrm{~mm}$. high and $4.8 \mathrm{~mm}$. in diameter, with vertical sides and thick gelatinous walls. Four radially situated clusters of marginal tentacles, each composed of about eight tentacles about as long as the bell height. On the lower side of each tentacle near the bulbous base there is a dark-colored ocellus. Fourstraight, narrow, radial canals. Manubrium wide, flask-shaped, and cruciform in cross section. About one-half as long as the height of the bell-cavity. Four radially situated clusters of oral tentacles, each of which branches dichotomously four times. These are very flexible, and their distal ends are knobbed.

Medusa buds arise from the eight adradii of the manubrium (Fig. 15); the youngest buds being immediately under and on both sides of the point of entrance of each radial canal, while older ones are found farther down the sides of the manubrium. The youngest buds (Fig. $15^{\mathrm{a}}$, Plate II) were small ovoid vesicles contained entirely in the ectoderm. The limiting membrane, $s l$, between the entoderm and ectoderm of the manubrium, in the neighborhood of tliese buds, was entire, and I could find no evidence of cells passing through it. Indeed, throughout the future development of the buds the entoderm re mained inert and its limiting membrane unbroken. The wall of the vesicle consisted of two layers of cells; an outer epithelium of ectodermal cells, e c $t$. $b$., destined to give rise to the ectoderm of the bud, and an inner layer of somewliat larger cells destined to give rise to the entoderm of the budding medusa, $e n t$. b. Fig $15^{\mathrm{a}}$. These latter cells, it will be observed, are entirely encased by the ectodern of the manubrium. Tliey may, however, have been derived at an earlier stage from the entoderm, and liave migrated into the ectoderm. Careful search has, however, failed to reveal evidence of any such migration, and in default of evidence to the contrary, we assume that these cells may be ectodermal in origin, altlough destined to produce the entoderm of the bud.

The central cavity of the vesicle is partially filled with a loose mass of 
umclei and cell naterial slowing little or no trace of cell boundaries (ce, Fig. $15^{\mathrm{a}}$ ). 'Tluese are present at all stages of the developing bud, patrially filling the gastro-vascular cavity, but they appear to decgenerate in later stages, and it seems possible that they serve to nourish the bud in its growth. This supposition appears the more probable from the fact that the gastro-vascular avity of the bud is neyer in connection with that of the parent medusa (see Fig. $15^{c}$ ). Fig. $15^{b}$ shows a young stage of the bud wherein the entoderm has become a cup-shaped vesicle, and the ectoderm is hollowing out to form the bell-cavity. Fig. $15^{\mathrm{c}}$ is a late stage showing that the limiting membrane, sl. of the manubrium of the parent medusa remains unbroken, and that the entoderm of the parent medusa, ent., never comes into contact with that of the bud, $e n t . b$.

\section{Netocertoides brachiatum, MAYER.}

Fig. \%, Plate $I$.

Marer, A. G., 1900; Bull. Mus. Comp. Zoöl, at Harvard Coll., Vol. XXXviI, p. 45, Figs. 4344 ; Pl. 18.

Bell $3.5 \mathrm{~mm}$. high, mitre-shaped, walls quite thin. Sixteen hollow tapering tentacles; one at the base of eacli of the sixteen radial camals. 16-25 small tentacles, one or two between each pail of the long ones. Longest tentacles are about one-quarter as long as the bell-height and their distal ends are tightly coiled. The short tentacles are hardly more than cirri. No marginal sense organs. Velum well developed. Eight main radial canals arise from the manubrium, but eacl bifurcates, giving sixteen radial canals, which extend straight toward the circular vessel. The eight proximal roots of the rarlial canals are bound to the manuluim by simple mosenteries. The manublum is broad and disk-like and the mouth is at the extremity of a short neck, and is surrounded by four simple lips. Conads within the eight main radial camals. The entoderom of the tentacles, radial rallals and manubrimm is resin-eolored. Quite common at the Bahantas, but rare at the Tortugas, relorida. Seen only in stmmere.

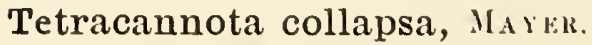

\section{Fig. S2, P'late IV.}

Mayen, A. G., 1900 ; Bull. Mus. Comp. Zoöl. at Harvard Coll., Vol. Xxxill, p. 46, Fịs. 14 16. Plates $7,8$.

Fewkes, J. W., 1883; Bull. Mus. Comp. Zoöl. at Inarrard Coll., Vol. XI, No. 3, Figs. i, ia.

llature medusa: Ball higher than a hemisphere and 7 mul. in dianeter, 
sixteen well developed, tightly coiled tentacles, and about 112 small marginal cirri. A rark brown entodermal ocellus is found near the base of each cirrus. There are sixteen radial canals, which arise from the gastric portion of the manubrium in four radially situated groups of four canals each. The manubrium has a wide basal peduncle which fills the major portion of the bell-cavity. Eight prominent recurved lips. The sixteen gonads are on the proximal parts of the sixteen radial canals close to the manubrium. Entoderm of manubrium dull yellow or green, and of tentacle-bulbs dull brownish yellow. Common at Bahamas and Tortugas, Florida, in summer.

\section{Willia ornata, MCCRADY.}

Fig. 12, Plate II.

McCrady, J., 1857; Gymn. Charleston Harbor, p. 47, Pl. 9. Figs. 9-11.

Agassiz, A., 1865 ; North Amer. Acal., p. 171. Figs. 274a-279.

Brooks, W. K., 1881; Studies Johns Hopkins University Marine Lab., Vol. II.. p. 144.

Willia gemmifera, Fewkes, J. W., 1882 ; Bull. Mus. Comp. Zoöl. at Harvard Coll., Vol. IX., p. 300 , Fig. 24, Pl. I.

Bell hemispherical, 5 mm. in diameter, with a small apical projection. There are sixteen marginal tentacles with well developed bulbs, each of which arises at the point of juncture betwe'n the radial vessels and the circular canal. Four radial canals arise from the manubrium, and each of these gives rise to three side branches, so that sixteen canals reach the circular vessel. Sixteen very slender tubes arise from the circular canal and each ends blindly within the gelatinous substance of the bell. Several distinct clusters of nematocysts are usually found on the ex-umbrella surface immediately over each of these tubes, although in some individuals there is but a single cluster over each tube. The manubrium is wide and flask-shaped, and provided with four prominent recurved lips. The gonads are situated at the four radial corners of the manubrium. The entoderm of the manubrium is sage-greenyellow, while the tentacle-bulbs are brownish. In every respect this medusa resembles the Willia ornata of Charleston and Newport harbors. It scems probable that Willia gemmifera is only a southern variety of this medusa which produces medusie asexually throngh budding at the points of juncture of the four radial canals with the manubrium. The only difference of specific value between gemmifera and ornata is that in the former there is but one cluster of nematocysts over the blindly ending diverticula of the circular vessel, whereas in W. ornata there may be one or several such clusters 
orer each diverticulun. The manubrium in $\mathrm{IV}$. gemmifera is long and slender while that of $\mathbf{W}$. ornata is short and broad; but these differences may be all due to the absence of sperm orowa in W. gemmifura. W. ornata is abundant at the Baluamas and is occasionally found at the Tortugas. W. gemmifera is found at the Tortugas and off the Carolina coast.

\section{Laodicea ulothrix, НАЕскеL. \\ Fig. 30, Plate IV.}

Laodice ulothrix, Haecked, 1879; Das System der Medusen, p. 133, Taf. VIII. Fig. 5-i.

Bell about $20 \mathrm{~mm}$. in diameter, and a little flatter than a hemisphere. 70-100 stiff tentacles about one-third as long as the bell-dianeter. These hare their distal ends coiled tightly. The tentacle-bulbs are large and hollow, and there is a dark brown ectodermal ocellus upon the inner (sub-umbrella) side of each bulb. Some of the tentacle-bulhs show spur-like projections upon the exumbrella side. Small sensory clubs and coiled cirri are scattered between the tentacles. The cirri are usually somewhat less numerous than the tentacles, while the clubs are about equal in number to the tentacles. There are no otoliths. There are four straight, narrow radial tubes. The manubrium is short and cruciform in cross section, with four recursed lips. The gonads are found on the four radial canals adjacent to the manubrium. 'The entoderm of the manubrimm, gonads, and tentacle-bulbs is rariable in color, being dull pink, brownish or greenish white. This medusa is abundant at the Canary Islands, Tortugas, and Bahamas.

\section{Tiaropsis punctata, MAYER.}

Fig. 21, Plate III.

Mayer, A. G., 1900 ; Bull. Mus. Comp. Zoöl. at Harvari Coll., Vol. XXXvir., p. 49, Figs. 60-63, Pl. 22.

Tiaropsis diademata, Fewkes, J. W.. 1882 ; Bull. Mus. Comp. Zoöl. at Harvard Coll.. Yol. IX., p. 277, Pl. VII.. Figs. 13-14

Bell about 4 mm. in diameter, bluntly cone-shaped or hemispherical, Four radially situated tentacles with well developed basal-bulbs and coiled distal ends. Four interadial tentacle-bulbs, and eight sense organs, two in each quadrant. Each sense organ consists of a pocket-like fold of the relum, containing 8-13 otoliths and immediately above them a lange pigmented eye spot. Four straight, marrow radial amals moon the mper portion of which the gonads are situated. The mambrimm is wide and flask-like, with four 
recurved lips. The entoderm of the manubrium, gonads, and tentacle-bulbs is reddish brown or dull yellow. Found at the Bahamas and Tortugas in summer. Not very common.

\section{Oceania McCradyi, Brooks. \\ Figs. 23-24, Plate III.}

Epenthesis McCradyi, Вrooks, W. K., 1888; Stıdies Johns Hopkins Univ. Biol. Lab., Vol. IV., p. 147-163, Pls. 13-15.

MaYer, A. G., 1900; Bull. Mus. Comp. Zoöl. at Harvard Coll., Vol. XXXVII., p. 50, Figs. 56-59, Pl. 21.

Adult Mcdusa: Bell flat; $12 \mathrm{~mm}$. in diameter. 20-25 slender tentacles, with well developed basal-bulbs. 20-25 simple otocysts, each containing a single otolith, alternating with the tentacles in position. Velum well developed. Manubrium quadrate, urn-shaped, and with four recurved lips. Four straight, slencler, radial canals. Four gonads, each at the centre of a radial canal. Elongate, slightly curved, club-shaped hydroid blastostyles are borne on the gonads of the male medusa. These blastostyles give rise to medusa by budding. When set free the medusæ are about $0.7 \mathrm{~mm}$. in diameter and have eight tentacles alternating with eight otocysts. The ectoderm of the blastostyle is directly continuous with that of the gonad from which it arises, but its entoderm is not in direct connection with that of the parent medusa. Supporting lamella of the bell pink, entoderm of gonads, manubrium and blastostyles dull greel sprinkled with gray pigment granules. Abundant in the Bahamas in summer; not found in winter. Rare at the Tortugas, Florida.

It is interesting to observe that Hartlaub, 1897; Hydromedusen Helgolands, has demoustrated that in Bougainvillia supreciliaris, and Margelopsis Haeckelii, some of the ova develop into planula within the ectoderm of the parent medusa.

\section{Epenthesis folleata, MCCrady.}

Figs. 16, 16a, Plate III.

McCrady, J., 1857; Gymn. Charleston Harbor, p. 98.

Brooks, W. K., 1882 ; Studies Johns Hopkins Biol. Lab., Vol. II., p. 138. Pl. 41.

Mayer, A. G., 1900 ; Bull. Mus. Comp. Zoöl. at Harvard Coll., Vol. XXXVII., p. 52, Fig. 139.

Bell flatter than a hemisphere, and about $5 \mathrm{~mm}$. in diameter. Sixteen marginal tentacles, alternating with sixteen otocysts, eacl containing a single otolitl. Four straight radial canals upon which, near to the circular vessel, are the four gonads. Manubrium small and urn-shaped, with four 
slightly recurved lips. Entoderm of manubrium, gonads and tentacle-bulbs usually green. Common off Bahamas, lolorida, and Carolina coasts in winter and spring. Rare after mid summer.

\section{Obelia sp. \\ Figs. 19-20, Plate III.}

Agassiz, A., 1888; Bull. Mure. Comp. Zoöl. at Harrard Coll., Vol. IX., p. 149.

MAYER, A. G.. 1900 ; Ibid., Vol. XXXVII., p. 52.

Bell flat and disk-like. Nbout $3 \mathrm{~mm}$. in diameter. Abont 100 stiff tentacles, each one-quarter as long as the bell diameter. Eight otocysts at the bases of eight of the tentarles, two in each quadrant. Four gomarls large and distended. When mature they lie near the middle of the radial eanals. Entoderm of manubrim and tentacle-bulls milky in color. Bell transparent. Common at the Bahamas, rare at Tortugas, Norida. Hỵdroid unknown.

\section{Eucheilota paradoxica, MAYER.}

\section{Figs. 1\%-18, Plate III; Fig. 65, Plate. III.}

MAYer A. G., 1900 ; Bull. Mus. Comp. Zoöl. at Harvard Coll., Vol. XXXriI., p 56, Fig. 134136, Pl. 40.

Mature Medusa: Bell about $4 \mathrm{~mm}$. in diameder, and more than a hemisphere, with a slight apical projection. Four large ladially situated tentacles each flanked by two short coiled cirri. The basal-bulbs of these tentacles are large and hollow. There are also four interradial rudimentary tentacle-bulbs,

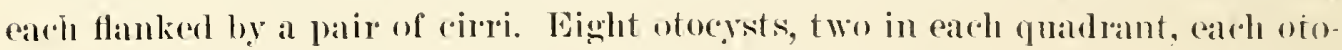
cyst bearing a single ofolith. Four straight slender radial canals in the middle of each of which the gonads are situated. Manubrimm small and flask-shaped, with fomr simple lips. Color of entoderm of mamnbrium, gonads and tentacle-bulbs dull milky green. In the roung medusa, the gonads are adjacent to the manubrim, lut they finally migrate down the radial camals so as to come to lie upon the middle of each canal. Medusa buds arise from these gonads. When set free each mednsa las fom well developed rabially sitmated tentacles as in the adult, but the interradial tentacle-bubs lack lateral airri. A mmber of the budeling medusie were killed in Finmminges fluid and sectioned, and it appears that both entoderm and ectoderm of the gonad of the parent take part in the formation of the bud which is thas formed, as are the merhasa buds of the Sarsiatar or those of the hydroids (Fig. 
65, Plate VII). It is interesting to see that even before it is set free the gonads of the budding medusa are well developed (b., Fig. 65).

\section{Phortis pyramidalis.}

Fig. 25, Plate III.

Eutima pyramidalis, Agassiz, L., 1862 ; Cont. Nat. Hist. U. S., Vol. IV., p. 363. Agassiz, A., 1865 ; North Amer. Acal., p. 118.

HakckeL, E., 1879 ; Das Syst. der Medusen, p. 191.

Phortis pyramidalis, Mayer, A. G., 1900 ; Bull. Mus. Comp. Zoöl. at Harvard Coll., Vol. XXXVII., p. 59, Figs. 21, 21a, Plate 10.

IIature Medusa: Bell about $35 \mathrm{~mm}$. in diameter. Slightly flatter than a hemisphere. The gelatinous substance is thick and rigid, and the manubrium is situated at the extremity of a wide, conical peduncle, which fills the greater portion of the bell-cavity. About 100 short tentacles alternating with 100 otocysts each containing a single otolith. No lateral cirri. Four narrow straight radial canals. Four gonads upon the radial canals near the circular vessel. Manubrium small and urn-shaped with four prominent recurved lips. Manubrium, gonads, and tentacle-bulbs delicate turquoise, other parts transparent. Common at Bahamas and Tortugas. Brilliantly phosphorescent at night, giving an intense blue-green light.

\section{Zygodactyla cyanea, L. Agassiz.}

Figs. 26, 27, Plate III.

Agassiz, L., 1862; Cont. Nat. Hist. U. S., Vol. IV., p. 361.

Agassiz, A., 1865; North Amer. Acal, p. 107. Fig. 159.

Mayer. A. G., 1900 ; Bull. Mus. Comp. Zoöl. at Harvard Coll., Vol. XXXvII, p. 60. Figs. 23, 23a, Pl. 11, Figs. 33, 34, Pl. 15.

Bell about $45 \mathrm{~mm}$. in diameter, flatter than a hemisphere. Gelatinous substance of the central part of the bell thick with a well developed peduncle, which projects downward into the cavity of the stomach. Peripheral zone of the bell thin and flexible. About 100 long tentacles and 100 simple straight radial canals upon which the linear gonads are situated. Each tentacle-bulb hollow and conical, and provided with a conical excretion papilla which projects outward from the exumbrella side of the bell. In addition to the well developed tentacles there are about 300 small rudimen-

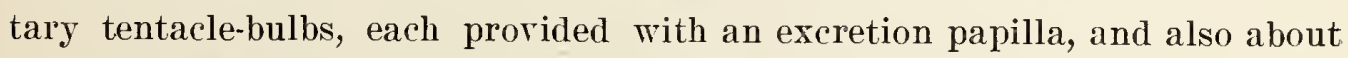
300 otocysts each containing two otoliths. The manubrium is wide and slablow and does not project beyond the velar opening. There are as many 
lips as there are radial canals. The radial canals enter the stomach at the highest point, and do not extend down the peduncle. The entoderm is delicate blue-green. Common off the Florida coast and Bahamas.

\section{Cladonema Perkinsii.}

Fig. 35, Plate IT.

Cladonema, sp., Perkiss, H. F., 1902 ; Johns Hopkius Univ. Circ., Vol. XXI., No. 155. p. 25. Figs. in text.

Bell half egg-shape; less than $2 \mathrm{~mm}$. in diameter. Bell-walls thin and uniform. Eight large unbranched tentacles, the distal ends of which bend ontward. The inner and lateral sides of each of these tentacles bear 3-10 flexible cirri which are besprinkled with wart-like clusters of nematocrsts and terminate in a knob. There is a large ectodermal, cup-like ocellus, with a lens upon the outer side of each tentacle bulb. Velum large, and with circular striations. Manubrium large and spindle-shaped with about six rounded protruding pouches at its widest part. Ifouth surrounded br fire oral tentacles, each ending in a ball of nematoçsts. The manubrium is thus octameral at top, hexameral in the middle, and a fire-pointed star at the month. Genital products derelop in the ectederm of a large part of the manubrium. Ocelli black, all other parts colorless. Fonnd br Dr. H. F. Perkins swimming on the surface at night in July, 1902, in Nassau Harbor. Balıamas.

Description and figure taken by permission from Dr. Perkins.

\section{THE OLINDIAD $Æ$.*}

The most characteristic medusie of the slablow water of the Bahama banks are species of Cubaia (Gonionemoides) and Olindias. These together with Olindioides, Gonionemms, Vallentinia, and possibly Limmocnida and Limnocodinm nua be gromped under a single famils.

Otindiade: With a ladd-like cluster of modified nematocrst cells mpon the aboral side, near the distal extrenity. of some or all of the tentacles. With fonr or six radial canals, and with or without blindly-ending centripetal canals. With gronads npon the radial(:andals.

* See Goto, S., 1903: Mark Auniversnry Volume, p. 3-22, I'ls. I.-III. Also, Perkins, H. F., 1903; Proc. Acac. Nat. Sci. Philadelphia. 1. $750-790,5$ Pls. 


\section{GENERA AND SPECIES.}

Gonionemus, Agassiz, A., 186*.

\section{Gonionemus.}

Gonynema, HАECKEL, 1879.

Gonionema Perkins, 1902.

Generic characters: With an adhesive disk near the distal extremity of each and all of the tentacles. Tentacles all similar each to each, and $\mathrm{pl}^{\circ} \mathrm{o}-$ jecting in a zone from the sides of the bell, above the margin, their entodermal cores traversing the gelatinous substance of the bell. Four gonads, ribbon-like and deflected alternately to one side and the other of the radial canals. No blindly-ending centripetal canals. Numerous otocysts upon the bell-margin.

\section{SPECIES :}

G. vertens, Gulf of Georgia, State of Washington; Alaska.

A. Agassiz, 1865; North Amer. Acal., p. 128; Murbach and Shearer, Proc. Zoöl. Soc., London, 1903, Vol. II., p. 183.

G. Murbachii, Wood's Holl, Massachusetts.

Murbach, 1895 ; Journ. Morphol., XI., 2.

Perkins, 1903 ; Proc. Acad. Nat. Sci., Philadelphia, 1902, p. 750-790, 5 Plates.

G. suvaensis, Sura Harbor, Fiji Islands.

Agassiz and Mayer, 1899 ; Bull Mus. Com. Zoöl., XXXII., 9.

G. Agassizii, Unalaska, Aleutian Islands.

Murbach, 1902 ; Annal. Mag. Nat. Hist., Ser. 7, IX., p. 73.

Murbach and Shearer, 1903; Proc. Zoöl. Soc., London, p. 185, Pls. XXI., XXII.

G. depressum, Yoliohama, Japan.

Gото, S., 1903; Mark Anniversary Volume, p. 12, Pls. II., 1 II.

Cubaia, Mayer, 1894.

\section{Cubaia.}

Gonionemoides, Mayer, 1900.

Generic characters: Tentacles are of two distinct kinds. Those of one set are provided with adhesive pads, as in Gonionemus, and project from a zone slightly above the bell-margin, their entodermal axes traversing the gelatinous substance of the bell. The other tentacles arise fron the bell-margin, and are provided with terminal clusters of nematocysts but not with adlesive pads. The gonads are papilliform. There are no centripetal canals. There are numerous otocysts upon the bell-margin projecting freely into the water.

\section{SPECIES :}

C. aphrodite, West Indies, Bahamas, Tortugas.

MaYer, 1894 ; Bull. Mus. Comp. Zoöl. XXV., p. 237.

Ibid (Gonionemus aphrodite) XXXVII., p. 62.

C. geophila, (Gonionemoides geophila); Bahamas, Florida.

MAYer, 1900 ; Bull. Mus. Comp. Zoöl. XXXVII., p. 62. Immatare medusa.

“Ireniopsis primordialis," Bull. Mus, Comp. Zoöl., 1894; XXV., p. 238. 
Vallentinia, BRowse, 1902.

\section{VALLENTINIA.}

Generic characters: Similar to Cubaia, excepting that the gonads are sac-like, and the otocrsts are "enclosed inside the margin of the umbrella." SPECIES :

V. falklandica; Falkland Islands.

Browye, 1902 ; Anual. Mrg. Nat. Hist, Ser. i, IX., p. 284.

Olindias, F. M̈̈́LER, 1861.

\section{Olindias.}

Halicaly $\mathrm{x}$, FEWres, 1882

Halicalyx, MAYER, 1900.

Olindias, Gото, 1903.

Generic characters: The tentacles are of two sorts. Those of one sort arise from the bell-margin, while those of the other set project from the sides of the bell, in a zone abore the margin, as in Gonionemus and Cubalia. There are pad-like clusters of nematocysts on the aboral side near the distal extremity of the tentacles. These may or may not function as adhesive disks. The gonads are papilliform. There are four complete radial canals, and a number of blindly ending centripetal canals. The otocrsts are at the sides of the tentacle-bases, above the relum, and project inward toward the bell carity.

\section{SPECILS:}

Olindias, Mulleri; Mediterranenn.

Haeckel, E., 1879; Syst. der Medusen, p. 2:3. T. af. XT., Fig. 10.

Goтo, S., 1903; Mark Anuivereary Volume, 1) 14.

Olindioides, Gото, 1903.

\section{OLINDIOIDES.}

Generic characters: Two sets of tentacles. Those of one set arise from the bell-margin, are higlrly contractile and armed with partial rings of nematocysts. The tentacles of the other set project at various levels from the sides of the bell, their entodermal cones traversing the gelatinous substance. They each bear an adhesive patch of ectodermal cells at ol meal their extremities; six gonads, one on each radial canal, ribbon-like, and fohled: six complete latdial cants, and numerous blindly-emling contripetal ressels. Otocysts as in Olindials.

\section{SPLCIISS :}

Olindıoides formosa, Misali, Jupnu.

Goto, S., 1903; Mark Anniversary Volume, p. 1.22, Pls. I., II.

Description mengre. Firrures lacking. 
The species of Olindiadse are few in number but are widely scattered. Nevertheless the geographical range of each species is remarkably restricted. It seems probable, therefore, that they belong to an ancient race that has suffered extinction in the greater part of the world.

They exhibit relationships both to the Eucopidae and Trachomedusi," and are distinguished by the fact that their primitive tentacles bear adhesive disks upon their aboral sides near their distal extremities. These primitive tentacles are retained throughout life, and project from the sides of the bell above the margiu. The marginal, or "velar," tentacles are phylogenetically recent, and arise quite late in ontogeny.

A study of the ontogeny of Cubaia and Olindias shows that the adliesive disks of their primitive tentacles are formed from modified nematocyst cells which gradually group themselves so as to form a cup-shaped or pad-like cluster.

ANALYSIS OF THE GENERA OF OLINDIADA.

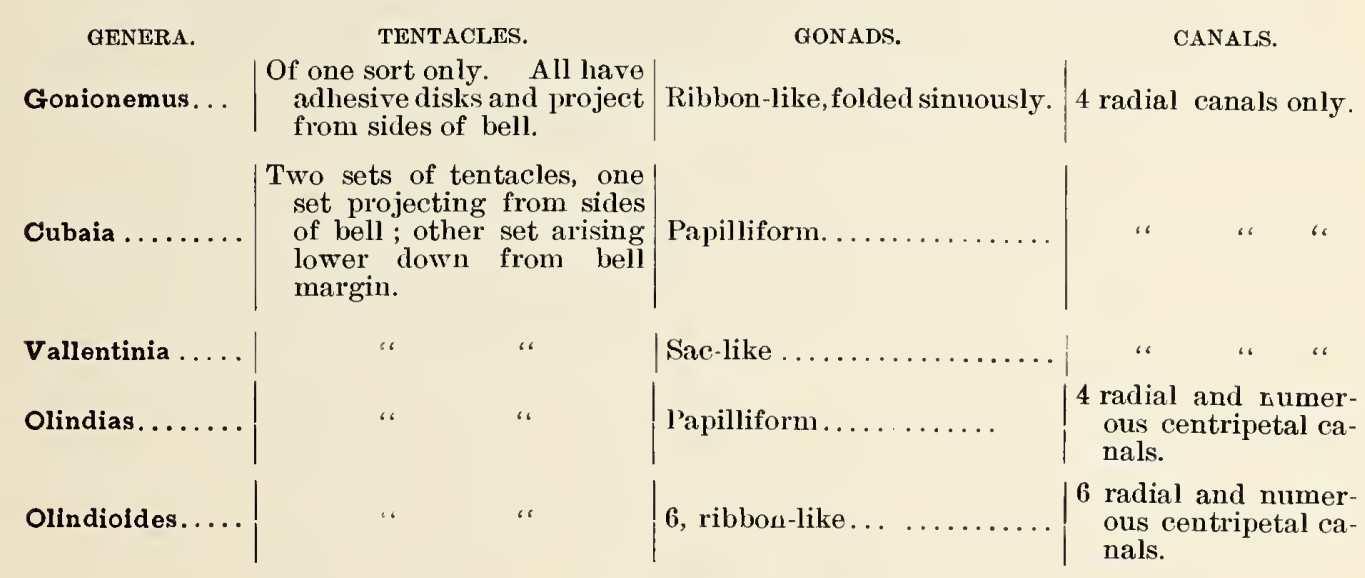

Cubaia aphrodite, MAYER.

Figs. 43-49, Plate $V$.

Mature Medusa: Figs. 45-49. Bell slightly flatter than a hemisphere and about $12 \mathrm{~mm}$. in diameter. About eighty tentacles. About twenty of these project from the sides of the bell in a zone above the bell-margin, their entodermal axes extending through the gelatinous substance of the bell. These tentacles are ringed at regular intervals with about eight nodular swellings containing nematocysts. On the aboral side near the distal end of each

* See Goto, 1903 ; Mark Anniversary Volume ; also Perkins, 1903 ; Proc. Acad. Nat. Sci. Philadelphia, 1902, p. $750-790$. 
tentacle, there is a large adhesice disk, while beyond this the extremity of the tentacle bends at a right angle to the main shaft. This extreme tip of the tentacle lears a large grape-like cluster of nematocrst cells (see Fig. 49).

The remaining 50-60 tentacles arise from the bell-margin at a lower level than the zone of origin of the adhesive tentacles. They are somewhat flexible, and project downward rather than outward. They have no adhesive disks, but are provided with 25-30 rings of nematocysts and terminate in a knob-like cluster of nettling cells (see Fig. 48).

There are about thirty-five otocysts each containing a single splerical otolith (Fig. 47). These otocysts all arise from the bell-margin close to the bases of the marginal (non-adhesive) tentacles. Ther project downward freely into the water. The velum is well dereloped. The circular ressel is simple and narrow and without centripetal dicerticulæ. There are four straight narrow radial canals; upon the mid regions of which are the papilliform gonads (see Fig. 45). The nranubrium is flask-shaped and there are four simple cruciform lips (see Fig. 46). The entoderm of the manubrium, gonads, and circular canal is dull rosin yellow. There are four green entodermal pigment spots upon the manmbriun near the points of junction of the four ralial canals. The internal endotrem of the bases of the adhesive tentacles is rich magenta-purple, while an intense green color extends a short distance outward into the endotermal shaft of the tentacle. The bases of the non-allhesive tentacles are dull green without the magenta color.

This medusa is very artive, swimming rapidly with a few powerful pulsations, and then slowly sinking down with tentacles ontspread. It often attaches itself to objects by means of its adhesive disks.

Development of the Iedusa: In a specinmen $1 \mathrm{~mm}$. in diameter (Fig. 43), the bell was higher than a hemisphere and the exumbrella surface regularly sprinkled with nematocysts. There were sixteen tentacles. The radial and interradial tentacles had as yet no adhesire disks but terminated in simple nematocyst knobs. The eight intermediate tentacles, however, had such disks, a condition exactly the reverse of which was observed in a young $\mathrm{C}$. geophila from Key West (see Bull. Mus. Comp. Zoöl. Harvard College, Vol. XXXVII, No. 2, Pl. 5, lig. 10). There were only four otocysts at this stage. and the mambrimm was londimentary.

When (i mul. in diameter (lig. 44) the bell is hemispherioal. There are about twenty sucker-bearing tentacles altermating with an equal mumber of 
nematocyst-bearing ones. There are twelve otocysts, and the manubrium is flask-shaped. The gonads, which begin to develop upon the radial canals at the four corners of the manubrium, have now migrated down the radial - canals, although they are still small and immature.

Cubaia geophila, of Key West, is closely allied to C. aphrodite and may be simply a variety of the latter. In C. geophila, however, we find none of the magenta-purple pigment at the bases of the tentacles. The bell is flatter, and the manubrium longer and more slender, and the edges of the radial canals, over the gonads, display dark colored, scattered pigment granules.

In $C$. aphrodite the gonads are developed upon the middle portions of the radial canals, while in $C$. geophila they are found upon the outer (centrifugal) halves of the canals.

\section{Olindias tenuis.}

Figs. 50-52, Plate V; Figs. 53-59, Plate VI.

Mature Medusa: Figs. 53, 54, 58, 59; Plate VI. Bell hemispherical, 35 nım. in diameter. Gelatinous substance quite rigid.

There are about ninety tentacles. Thirty-two of these are straight, about one-third as long as the bell-diameter, and arise from the sides of the bell in a zone at a short distance above the margin. These tentacles are besprinkled with wart-like clusters of nematocysts, and near their distal ends on the aboral side one finds an elongate, pad-like cluster of nematocyst cells, having a sucker-like appearance, although there is no evidence that it actually functions as an organ of adhesion. (Fig. 57, Plate VI.)

In addition to the short, straight tentacles there are about sixty others which are very flexible, and are often seen coiled in close helices. When extended these tentacles are about four times as long as the bell-diameter. They arise from the bell-margin below the zone of origin of the straight tentacles. A powerful strand of longitudinal muscle fibres extends throughout the entire lengtl of the outer side of each of these velar tentacles, while half rings of nematocysts are found at regular intervals upon their inner sides.* (See Figs. 54, 58). The tentacles are tlius comparable in their structure to the long ones of Physalia. They terminate in a knob-like cluster of nematocysts, and upon their aboral sides near the distal end there is a flat pad-like cluster composed of very elongate and thickly crowded ectodermal cells. (Fig. 58a.)

* According to Goto, 1903, similar rings are found on the outer sides of the velar tentacles in Olindioides. 
In addition to the tentacles there are about sixty-four bluntly rounded papillax npon the bell-margin.

There are sixty-fomr otocysts, a palir on cither side of the origin of each and every one of the short, straight tentacles. Ealch otocyst contains a sinale splereical otolith.

There are four straight narrow radial wanals and twenty-eight direrticulie, which extend inward from the circular ressel, and end blindly in the grelatinous substance of the bell. The otocysts flank the sides of these radial canals and diverticulae (see rig. 53).

The four gonads are papilliform and are developed upon the outer halves of the four radial canals (see Fig. 59 )

The manubrium is tubular, cruciform in cross section and clongate, and has four recurved lips. It extends about three-quarters of the distance from the inner centre of the bell cavity to the velar opening.

'The gelatinous substance of the bell is of a dolicate greenish rellow. The entoderm of the manubrium gonads and tentacle bulls is oparue yellow-green. with the immermost parts purple. There are four interradial, reddisl purple. pigment spots upon the manubrium near the points of origin of the radial canals. The nematocyst-warts upon the short tentacles are either white or dark purple, while the half-rings on the long, flexible tentacles are red and yellow.

Development of Medusa: The youngest medusae (lig. 50. Plate V) observed were about $0.7 \mathrm{~mm}$. in diameter, the bell being higher than a hemisplere and the exumbrella surface regularly besprinkled with nematocysts. 'There were eight tentales, four radial and four interradial. These all be lomged to the short, straight, "adhesive" set and projected from the sides of the bell above the bell-margin. There were only four otocysts, one at the base of aach interradial tentacede. The radial canals were narrow and straightelged, amel the circular vessel was simple without rentripetal diverticular. The mamuluiun was quadratic, and very short.

As the modusa grows its bell increases in height relatively faster than in widh, so that it becontes higher than a hemisphere and resembles in shape the bell of bougainvillia. When :3 ntm. high (Fig. 61. Plate V) there are still only gight tentaleles, but the radial amals hatre become broad with serrate edges, and fom interralial diverticula begin to devolop from the eireular vessel. The eight tontarles have greatly alongated and torminate in simple nematoegst- 
knobs (see Fig. 55, Plate VI). When the medusa is $8 \mathrm{~mm}$. in diameter (Fig. 52, Plate V), there are sixteen of the tentacles that project fiom the sides of the bell, and about an equal number of the flexible, coiled tentacles that arise from the bell margin. There are tlirty-two otocysts, a pair flanking each of the sixteen tentacles that arise from the sides of the bell, and twelve centripetal diverticula from the circular vessel that extend into the gelatinous substance of the bell. The gonads have not yet inade their appearance. The tentacles that arise from the sides of the bell liave begun to develop their peculiar pad-like disks upon their aboral sides (see Fig. 56, Plate VI). These pad-like disks, which are evidently homologous with the adhesive disks in Gonionemus and Cubaia, are developed from the aboral side of the primitive nematocyst knob of the tentacle, as is shown in successive stages represented in Figs. 55, 56, 57, Plate VI. We see, then, that the youngest medusa of Olindias nay be said to be in the "Gonionemus stage," for it has only tentacles of the "sucker-bearing" set, and the circular canal is simple witlout diverticula. It seems probable therefore that Olindias is descended from a Gonionemuslike medusa.

Olindias tenuis is one of the few medusa that thrive best on the sliallow flats of the Baliamas and Florida coast, and is very abundant during the summer montlis in Nassau Harbor, and at Key West, Florida.

\section{Lixiope scutigera, McCrady.}

Fig. 31, Plate IV.

Brooks, W. K., 1886 ; Mem. Bost. Soc. Nat. Hist., Vol. III, p. 373, Pl. 41, 42.

McCradx, J., 1857 ; Gymn. Charleston Harbor, p. 106.

Xanthea scutigera, HAECKEL, E., 1864 ; Geryoniden, p. 24.

Liriantha scutigera, HA EckeL, E., 1879 ; Syst. der Medusen, p. $28 \%$.

Adult Medusa: Bell bluntly conical, flatter tlan a liemisphere, and about $8 \mathrm{~mm}$. in diameter. Four long, lollow, radially situated tentacles. In young specimens there are four short, stiff, solid, radial tentacles that project from the sides of the bell, but tliese are cast off or absorbed before the medusa is mature, and are replaced by the hollow, permanent tentacles. There are eiglit otocysts, each luaving a single spherical otolith. The otocysts project inward into the bell cavity above the velum and are radial and interradial in position. Tlie velum is well developed. There are four slender radial canals and a simple narrow circular vessel without centripetal diverticulæ. The manubrium is at the extremity of a long tapering peduncle which projects beyond the velar opening. The four cruciform lips are curtain-like and folded and 
there is a well developed "tongue." The four heart-shaped gonads are found upon the radial canals immediately above the circular vessel. The entoderm of the manubrium is green. Common in the West Indies and Florida region and occasionally drifted upon the New England coast in summer.

\section{Glossocodon tenuirostris, FEWKES. \\ Fig. 33, Plate IV.}

Fewres, J. W., 1882 ; Bull. Mus. Comp. Zoöl. at Harvard Coll., Vol. IX., p. 278, Pl. VII.. Figs. 1-9.

Liriope cerasiformis, Maas, O., 189:3; Ergeb. der Plankton Exped., Bl. II.. K. C., p. 35, Taf. II., Figs. 5, 6.

Liriope tenuirostris, Agassiz, L., 1862 ; Cont. Nat. Hist. U. S., Vol. IV., p. 365.

Bell bluntly conical, $7 \mathrm{~mm}$. wide. Four long, lollow, tapering, radial tentacles ringed at regular intervals. Four short-stiff, interradial, club-shaped tentacles which project upward from the bell-margin. Eight otocysts on inner side of bell cavity, one at base of each tentacle. Velum well developed. Manubrium slender, about as long as the width of the bell. Pedincle short and conical. Four lips, simple, cruciform, and studded with nematocysts. Four broad radial canals. Circular vessel broad with four blindly ending centripetal diverticulie. Fonr gonads at the middle of each of the four radial canals. Entoderm of manubrim green, lips and long hollow tentacles pink.

Abundant in Bahamas, West Indies, and Tortugas. Occasionally drifted northward to the sonthern coast of New England.

\section{Aglaura hemistoma, l'Éron and LEsúur.}

$$
\text { Fig. S4, Plate } I V \text {. }
$$

Péron, F. ét Lesuevr. C. A., 1809; Tablea des Meduses, 1. 351, No. 73.

Bell rylindrical 4 mm. high, with vertical sides and flat top. Bell-walls very thin but quite rigid. 'Tentacles numerous but very brittle, so that they ane nsially fouml to be broken ofl short. Eight small marginal otocysts. Velum well developerl. Eight slender, straight, ladial canals. Manubrium flask-shaped wilh four curved lips. A rylindrical peduncle above the mambrium. Eight samsage-shaped gonads arise from the proximal part of the gastric portion of the mambrimm. The entolerm of the manubrinm is rosinbrown. Common in West Indian region and Tropical Atlantic. 


\section{Aegina rhodina, Hä́KеL.}

Figs. 28, 28a, 29, Plate IV.

HaedKel, E. 1879 ; Das Syst. der Medusen, p. 338, Taf. XX., Figs. 11-15.

Bell of mature medusa $40-50 \mathrm{~mm}$. wide. Of the specimen figured by us, $7 \mathrm{~mm}$. Sides of bell sloping; apex rounded. There are four tentacles each about as long as the bell-dianeter, their entodermal cells are disk-like, and a single row of nematocysts extends down their outer sides (see Fig. 29). Tliese tentacles arise from the sides of the bell half-way between the margin and apex. There are twelve sense organs upon the bell-margin, each containing two crystalline otoliths (Fig. 28a). The velum is well developed. The gastric portion of the llanubrium surrounds a conical mass of gelatinous substance which projects from the inner apex of the bell cavity and occupies the centre of the stomach. The mouth is a simple round opening. There are eight genital pouches, two in each quadrant. Their outer edges are quadratic, and they are separated by a very small space. The genital organs and tentacles are delicate pink, while tle gastric part of the manubrium is intense green. A single immature specimen was found at Mastic Point, Andros Island, Ballanias, in a surface tow on June 20, 1903. Haeckel found three specimens in the Canary Islands in January, 1867.

Haeckel's description accords with ours, excepting that he finds sixteen instead of twelve marginal sense organs; and he states that the stomach is pale.reddish instead of intense green as observed by us.

\section{Cunoctantha, sp.}

Figs. 36-40, Plate IV.

A budding nurse, or stolon, of Cunoctantha was found floating freely in the water at the Tortugas, Florida, in July. Only one end of this stolon was perfect, the other extremity being in a state of advanced disintegration so that its form was indeterminate. It was, therefore, somewhat remarkable that the budding end of the stolon was apparently in a perfect healthy condition and survived for a whole day in the aquarium, giving rise to medusæ in considerable numbers. It is possible that the disintegrated end of the stolon was being absorbed to provide nutriment for the budding end, but this is a mere conjecture.

Figs. 37-41 represent successive stages in the formation of the medusabuds. The bud is at first pyriform, and then its base becomes surrounded by a collar destined to form the medusa-bell. The eight tentacles and eight 
otocysts develop simultaneonsly. When set free the medusa has eight well developed tentaceses, and eight marginal sense organs; each containing two spherical otoliths (Figs. 41, 42).

\section{SCYPHOMEDUSAE.}

Tamoya haplonema, F. MëLLER.

Figs. 61-64, Plate TII. (Fig. 60?.)

Mứcler, F., 1859 ; Abhand!. Naturf. ges. Halle, Bd.V.. p. 1, Taf. I., II.

Agassiz, L., 1862 ; Cont. Nat. Hist. U. S., Vol. IV., p. 1 it.

HaEckel, E., 1880; Syst. der Medusen, p. 443.

Young medusa? "Tamoya punctata," Fewres, J. W., 1883; Bull. Mus. Comp. Zoöl. at Harvard Coll., Vol. XI., No. 3, p. 84, PI. I., Figs. 4-6.

The young of the Charybeida are so different in appearance from their adults, and the characteristic structures, observation of which is necessary for their classification, are so late in dereloping that it is all but hopeless to attempt to determine them. For example: the yomg specimens ealled "Tamoya punctata" Fewkes (Fig. 60, I'late VII) are exceediugly abundant in the Bahamas during the spring and summer, whereas the adult is unknown. When yomg they swim near to the surfiace while it seems probable that the adults sink to the bottom.

Howerer, the goung "Tamoya punctata" latelis all trace of gastric cirri, gonats, velar canals, or well developed pedalia; and we are therefore unable to state whether it be the yommen of Tamoya or Claryblea. Moreorer, the eximulerella of the poung Charybeida are ustally hesprinkled with prominent. more or less pigmented, clusters of nematocysts which are often arranged in definite rows. 'These ather lose their regnlar order or become much less promincent in the alult, so that while they are a most conspicuous feature of the young they are quite inconspicuous in the matme animal. We see, therefore, that the names of immature forms, such as "Tamogal punctata," Fenkes;

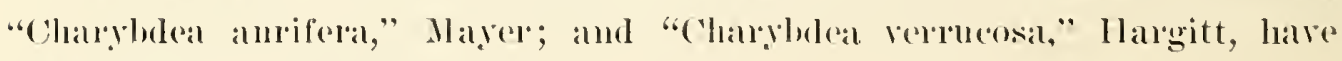
pratctically no signiticance.

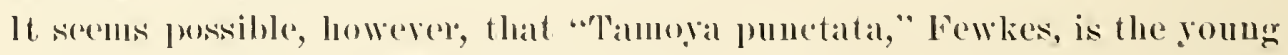
of 'Tamogal haplonemal, F'. Mïller.

T'amogat haplonema is widely distributed, having been fomm on the coast of Brazil; in the West Indies; at Beanfort, North Carolina; and in Great

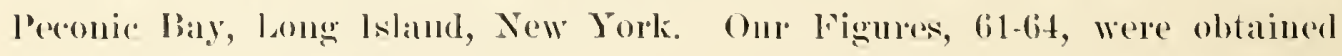

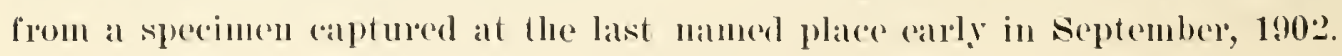


A number of specimens of this medusa, in various stages of growth, were obtained at this time. They were all captured in a dredge at a depth of two fathoms, about one quarter of a mile off Brown's Point, Great Peconic Bay, where the bottom was covered with drifting sea-weed. None were seen upon the surface.

\section{Adult Medusa, Tamoya Haplonema. \\ Figs. 61-64, Plate VII.}

Bell $90 \mathrm{~mm}$. higl, $55 \mathrm{~mm}$. wide; with vertical sides and relatively flat top. Exumbrella surface thickly covered with white wart-like clusters of nematocysts. Four pedalia, $30 \mathrm{~mm}$. long, wing-like and sharp-edged. Tentacles 90 mm. long, hollow, very flexible, and bearing regularly spaced rings of nematocysts that are capable of inflicting a severe sting to the liand. The sensory clubs (Figs. 63, 64) have two large median, and four small lateral eyes, all being upon the inner side of the bulb. The large eyes are provided with prominent convex lenses and are ectodermal. There is a large terminal entodermal otolith composed of a mass of concretions.

The velarium is well developed, and there are ten dendritic velar canals in each quadrant which terminate in numerous, non-anastomosing branches (see Fig. 62).

The nervous ring running from the base of each pedalium to the sensory clubs is distinctly visible as a white colored cord.

The stomach extends about one-third of the distance from the inner apex to the level of the valarium, and there are four shightly recurved lips. The gastric cirri are short and numerous.

The genital organs are curtain-like with frilled edges. They project from the interradial septae into the gastro-vascular pouches of the bell on either side. There are thus eight curtain-like sleets projecting into the four radial pouches. In old specimens the gonads are so large that their free edges overlap beyond the central line of each pouch.

The gelatinous substance of the bell is transparent. The long, flexible tentacles are a milky yellow, often with a faint purple-hue. There are large white wart-like clusters of nematocysts over the pedalia and valarium. The genital organs are milky-yellow, and the eyes dark brown.

This medusa is exceedingly active, and the gelatinous substance of its bell tough and rigid. 


\section{Nausithö̈-punctata, KöLLIKER.}

Kölutkra A, 18i3; Zeit. für Wissen. Zö̈l. Bd. IV, p 323.

Nausithoë albida, CArus, T., $185 \pi$; fcones Zootom. Taf. II, Fig. 17, 22, 23, var. pacifica AaAsSiz, A. and Mayer, A. G., 1902 ; Mem. Mus. Comp. Z, ;l., Vol. XXVI, p. 15; Pl. 7. Fig. 32.

This medusa is abundant in the Balamas, Tortugas and Iediterranean during the summer months, and a closely allied variety is found in the Tropical Pacific.

\section{Linerges mercurius, НАECKEL.}

Haeckel, E., 1880 ; Syst. der Medusen, p. 495, Taf. XXIX, Fig. 4-6.

The young ephyrx of this medusa appear in rast numbers in the Bahamas in March and grow rapidly to maturity, disappearing before the first of June. A rlosely allied species, Linerges aquila, is common in November and December in many of the lagoons of Atolls in the Tropical Pacific.

\section{Aurelia habanensis, MaYer.}

Mayer, A. G., 1900, Bull. Mus. Comp. Zoöl at Harvard Coll., Vol. XXXVII, p. 69, Figs. 73. 74, Pl. 24 ; Fig. 86, Pl. 26.

The ephyre of this species appear in considerable numbers in June and July, and mature indiriduals are abundant in August. Mature specimens are also found in Havana harbor in February.

\section{Cassiopea frondosa, LAMARCK.}

LAMARCK, J. DE., 1817 ; Hist. anim. sans vert., Tom. II. p. 512.

Medusa frondosa, Paldas, P. S., 1774 ; Spicilegia Zoöl. Fasc. X, p. 29, 30 ; Pl. 2, Fig. 1-3.

Cassiopea frondosa, Tulesius, W. G., 1834; Beitrage zur Nat. der Medusen, Acrd. Cros. Leop. Nova Actr. Tom. XV. p. 263, 278; Tab. LXXII, Figs. 1-5̃.

Polyclonia frondosa, Agassiz, L.. 1860 ; Cont: Nat. Hist. U. S., Tol. III, Pls. 13, 13a.

This medusa is locally abundant in spring and summer. It prefers muddy bottoms where the water is not very pure and often remains motionless for long periods of time with its disk pressed against the ground, its oral side and montls arms being uppermost.

It is abmulant in .June and .Tuly in the moat of Fort .Tefferson, Dry Tortugas, Floricla.

\section{Siphonophoræ.}

The Siphonophorar of the Bahamas are spereies common also to the Tropical Atlantic. They ale more abmolant at the surface in winter than in summer, when they probably sink to a comsiderable depth.

\section{Ctenophoræ.}

Bolina vitria is abumlant over the shallow bauks in summer, while Beroë Clarkii is fouml commonly in the spring. 


\section{EXPLANATION OF THE PLATES.}

\section{PLATE I.}

Fig. 1. Lymnorea Alexandri, nov. sp., Half-grown medusa.

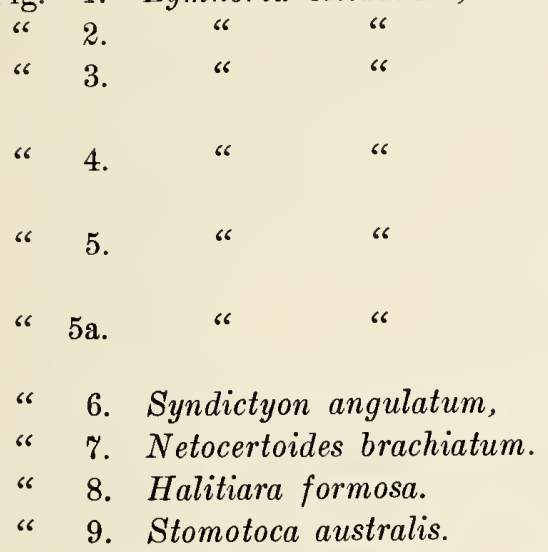

Full-grown medusa.

Side view of tentacle showing ectodermal ocellus.

Side view of manubrium showing nematocyst knobs.

Enlarged view of a nematocyst knob of manubrium.

Section of swollen portion of radial canal showing vacuolated entodermal cells.

Mature medusa.

Mature medusa.

\section{PLATE II.}

Fig. 10. Dissonema turrida.

"11. Tiara superba.

"12. Willia ornata.

“ 13. Hybocodon Forbesii.

"14. Bougainvillia niobe.

" 15

66

66

“ $15 \mathrm{a}$.

" $15 \mathrm{~b}, 15 \mathrm{c}$.
Mature medusa.

Mature medusa.

Mature medusa.

Mature medusa.

Section of the manubrium showing medusa buds, in various stages, developing within the ectoderm (ect). The entoderm, and the limiting membrane $(s l)$ remaining unbroken and inert

Very young bud (ent. $b$ ), entoderm of the bud. (c) Mass of cells within the central cavity of the entoderm. These probably contribute to the nutrition of the bud.

Successive stages in the development of the medusa buds. Lettering as in previous figures. 


\section{PLATE III.}

Fig. 16. Epenthesis folleata. 16a.

“ 17. Eucheilota paradoxica.

" 18. " "

"19. Obelia sp.

"20. " tentacle and otocyst.

“21. Tiaropsis punctata.

“ 22. Parvanemus degeneratus, gen. $є t$ sp. nov.

"23. Oceania McCradyi.

"24. "

“25. Phortis pyramidalis.

" 26. Zygodactyla cyanea.

" $2 \%$. " "

Fig. 28. Aegina rhodina, 28a.

" 29. " "

"30. Laodicea ulothrix.

"31. Liriope scutigera.

“32. Tetracannota collapsa.

“33. Glossocodon tenuirostris.

"34. Aglaura hemistoma.

“ 35. Cladonema Perkinsii.

“36. Budding stolon of Cunoctantha.

" 37-41. Successive stages in the development of medusa-buds on the stolon of Cunoctantha shown in Fig. 36.

" 42. Marginal sense organ of the medusa of Cunoctantha when about to be set free.

PLATE $V$
Fig. 43. Cubaia aphrorlite.

$\begin{array}{llll}\text { " } & 14 . & \text { " } & \text { " } \\ \text { " } & 45 . & \text { " } & \text { " } \\ \text { " } & 46 . & \text { " } & \text { " } \\ \text { " } & 47 . & \text { " } & \text { " } \\ \text { " } & 48 . & \text { " } & \text { " } \\ \text { " } 49 . & \text { " } & \text { " } \\ \text { " } 50 . & \text { Olimdias tenuis. } \\ \text { " } 51 . & 52 . & \text { " } & \text { " }\end{array}$

Side view of manubrium.

Young medusa.

Medusa-bud about to be set free.
Mature medusa.

A medusa-bud from one of the hydroid blastostyles.

Portion of bell margin.

PLATE IV.

Otocyst.

Tentacle.

Mature medusa.

Young medusa.

Mature medusa.

Copied by permission from a drawing by Professor H. F. Perkins, in Johns Hopkins University Circulars, Vol. XXI, No. 155.

Young medusa.

Half-grown medusa.

Full-grown medusa.

Manubrium of Fig. 45.

Otocyst.

One of the velar tentacles.

One of the sucker-bearing tentacles.

Young medusa.

Older than liig. 50.

Half-grown medusa. 


\section{PLA'TE VI.}

Fig. 53. Olindias tenuis.

“ 54.

" 58.4 "

" 58a. " " "

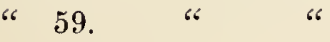

" $55-57 . \quad$ "

Mature medusa.

Side view of bell-margin, showing that the short tentacles arise from the sides of the bell above the margin, while the long flexible tentacles arise from the bell-margin. The short tentacles have each a sucker-like, nematocyst-pad upon the aboral side of their distal ends; while the long flexible tentacles have numerous half-rings on their inner, and a well developed strand of longitudinal muscle fibres upon their outer sides.

Successive stages in the development of the sucker-like nematocyst-pad upon the aboral side of the short tentacles in medusæ the diameter of whose bells are respectively $2 \mathrm{~mm} ., 8 \mathrm{~mm}$. and $16 \mathrm{~mm}$.

Side view of a portion of one of the long tentacles showing the half-rings of nematocysts on the inner and the strand of longitudinal muscle fibres on the outer side.

Extremity of one of the long flexible tentacles showing the terminal knob of nematocysts, and the pad-like thickening upon the outer side of the tentacle, composed of closely crowded elongate nematocyst cells.

View of one of the gonads.

\section{PLATE VII.}

Fig. 60. "Tamoya punctata," Fewkes.

" 61. Tamoya haplonema, F. Müller. Side view, natural size. Specimen from Great Peconic Bay, Long Island, New York.

"6 62.

View of canals in the velarium.

"63. " 6

"64. 6 6

The sensory club seen from the centripetal side.

The sensory club seen from the side, showing ectodermal eyes, and entodermal otolith.

" 65. Section through the gonad of Showing that the entoderm and ectoderm Eucheilota paradoxica. of the bud are derived directly from the same layers of the gonad. ect, ectoderm; ent, entoderm. $b$, gonad of the budding medusa. 



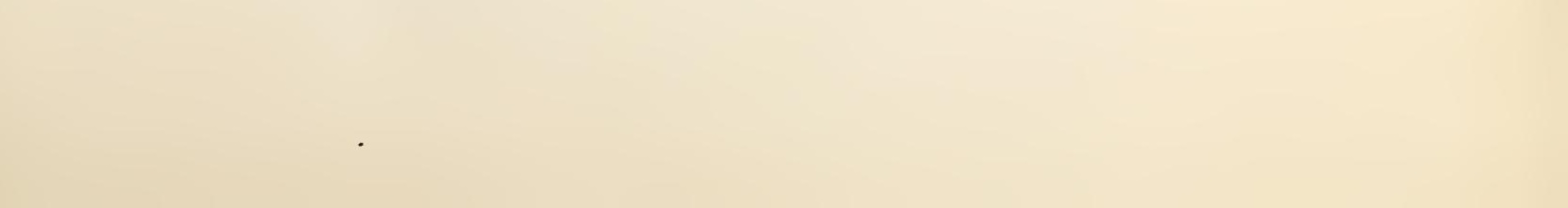


LIBRARY

(IF THE

UNIVERSITY OF I'L:AOIS 
I'I. I.

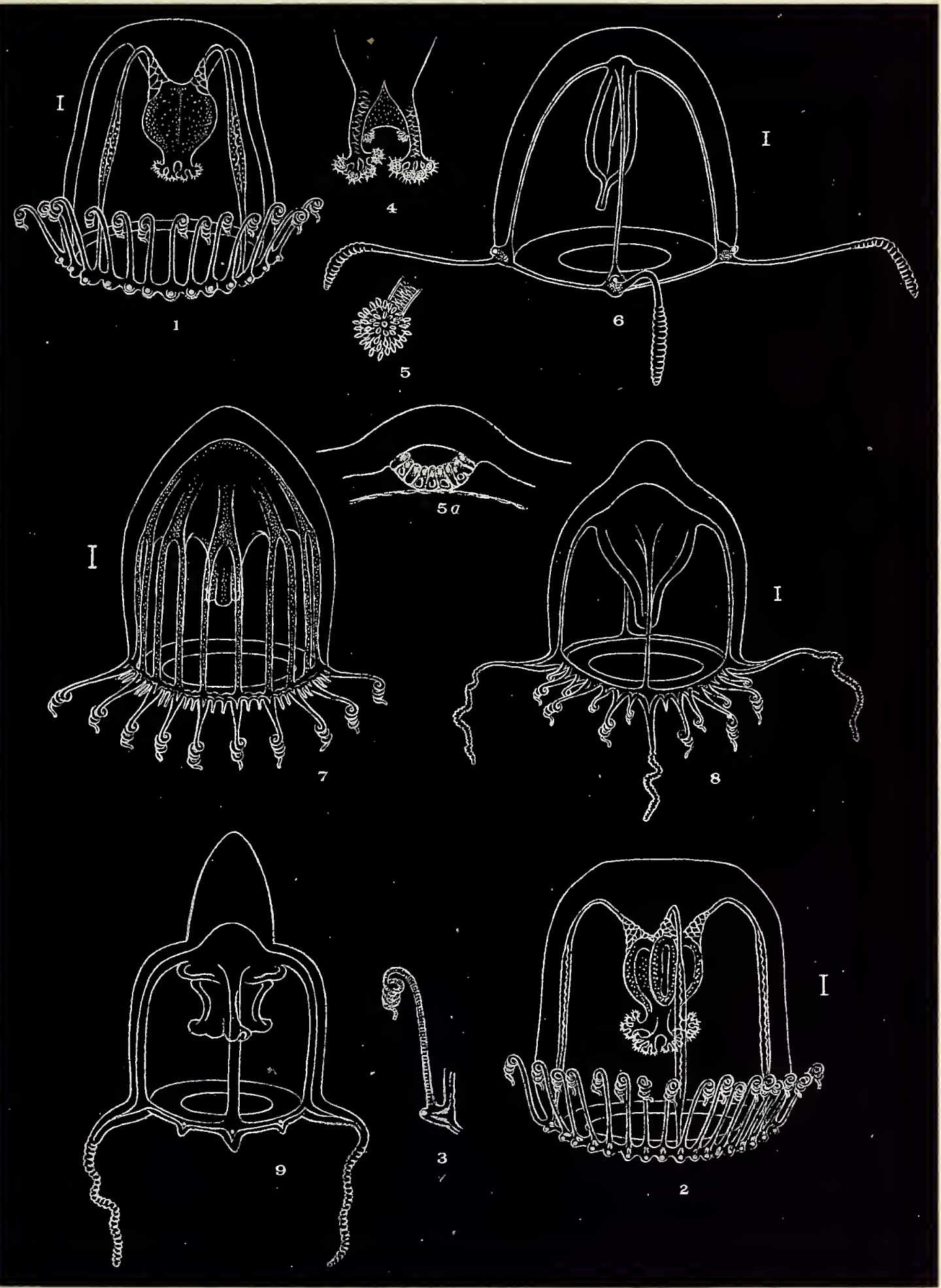

A. G. M. DEL. 
$\operatorname{lic} 2: \therefore$

OF THE

UNIVERSITY of ILLINOIS 


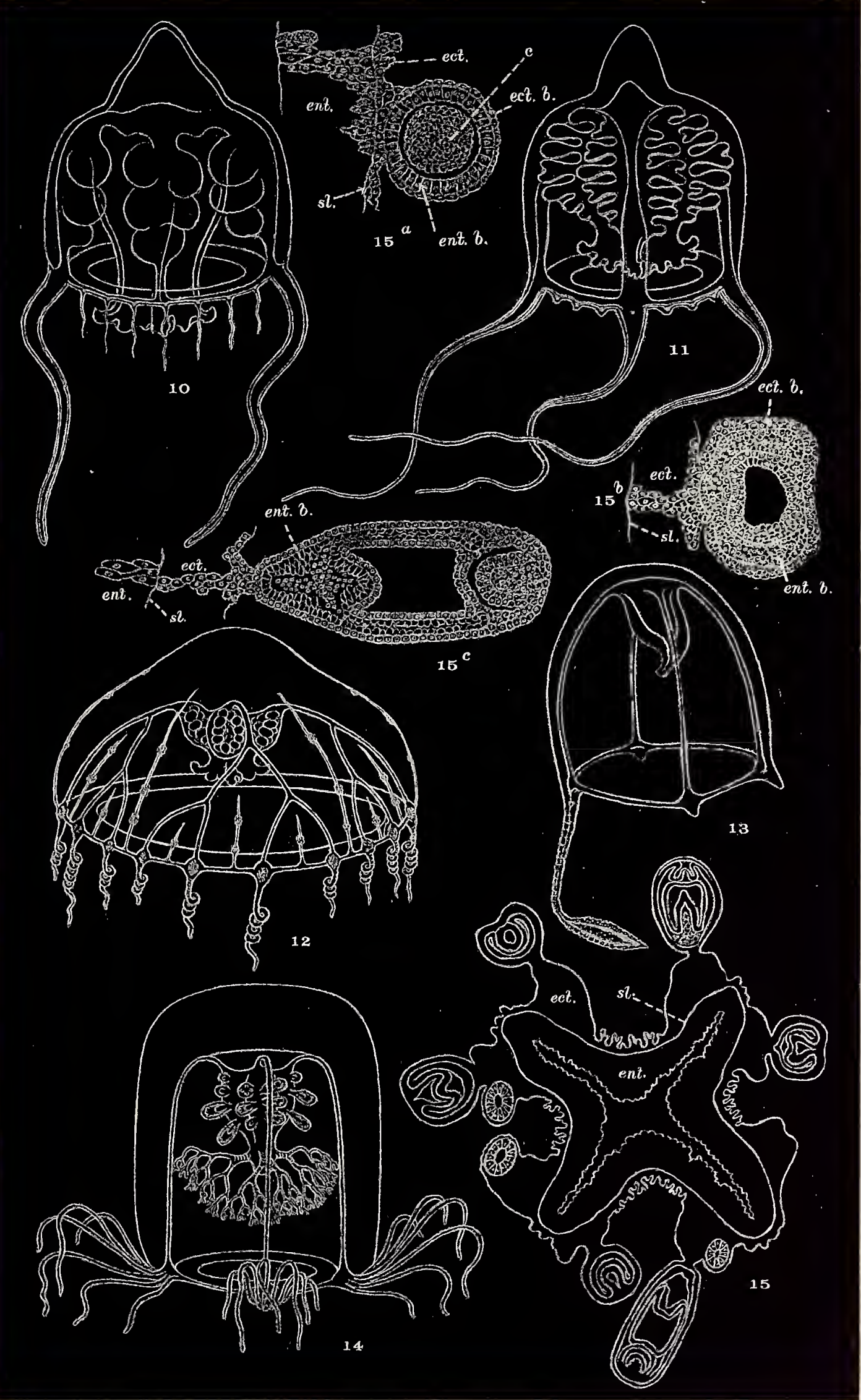


Licลa.:

UNIVERSITY OF ILLINOIS 


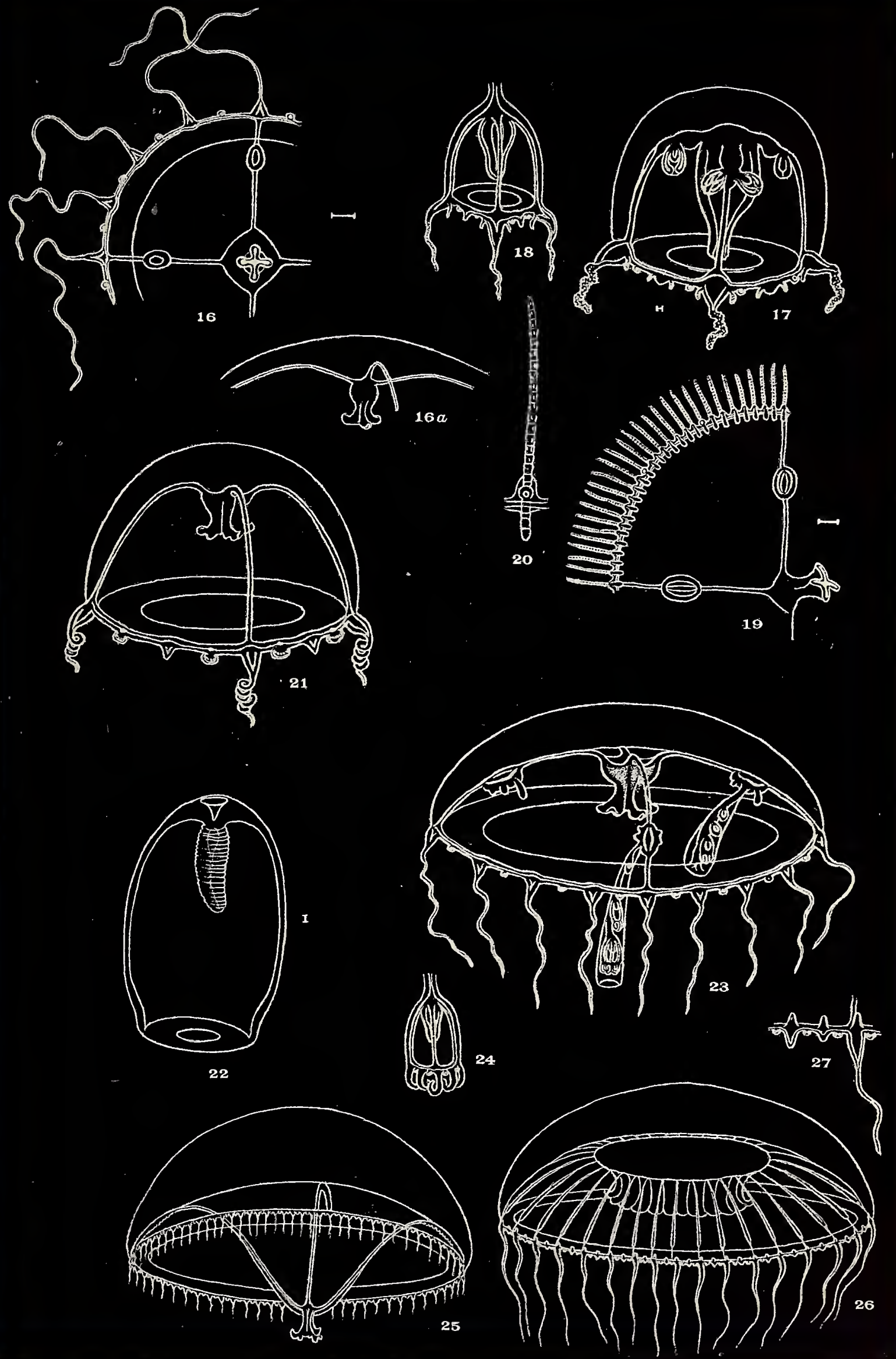




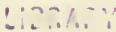

C! :lic

UNIVERSITY OF ILLINOIS 

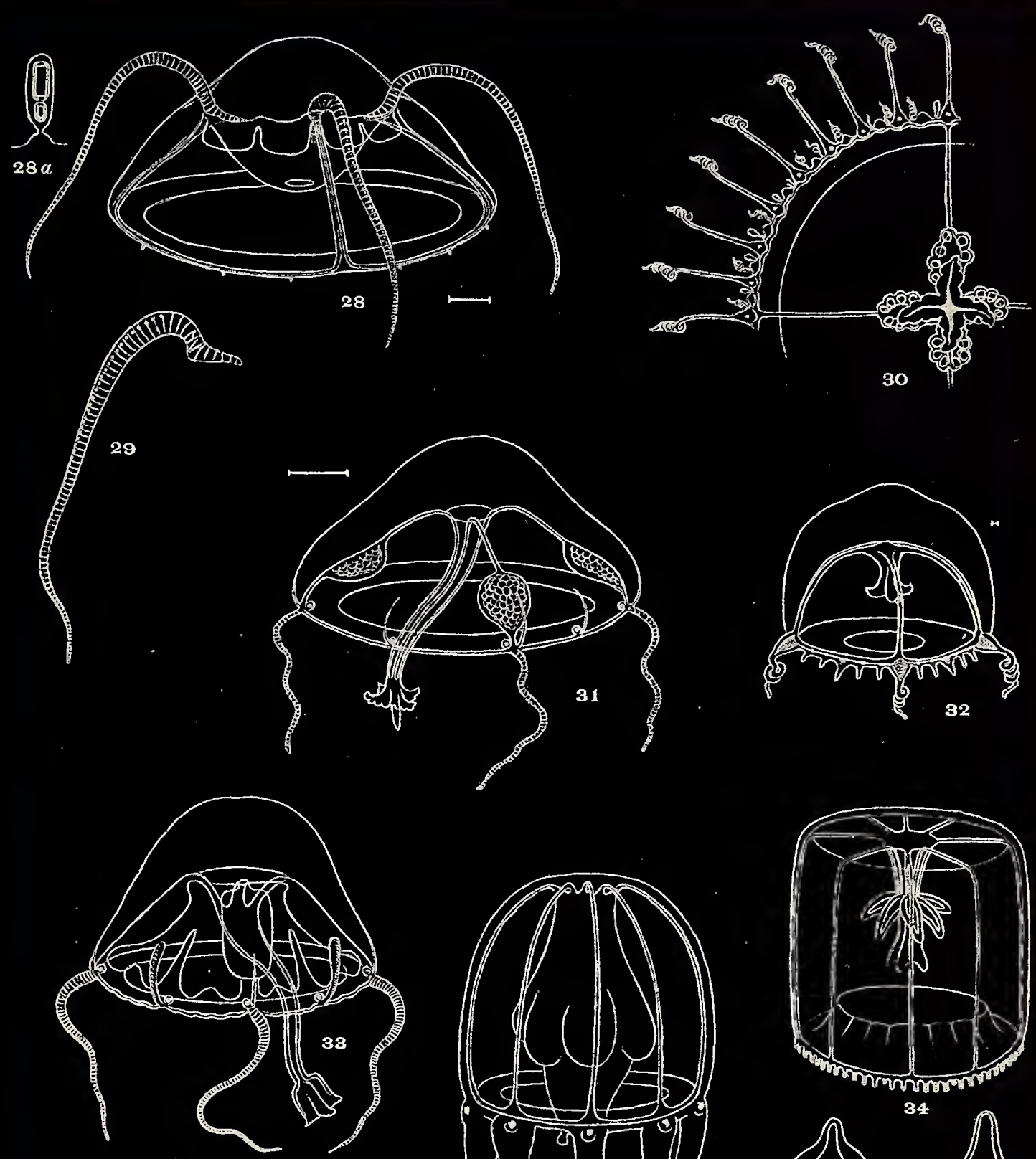

(4) Gis do (0) $\xi_{03}$

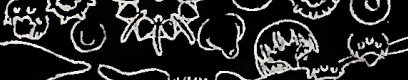

$$
{ }_{36}
$$

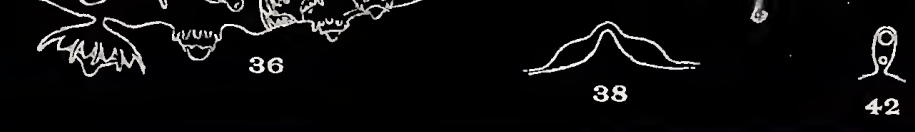

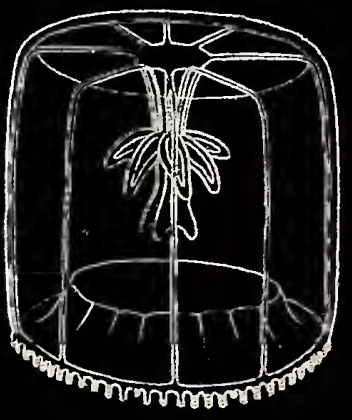
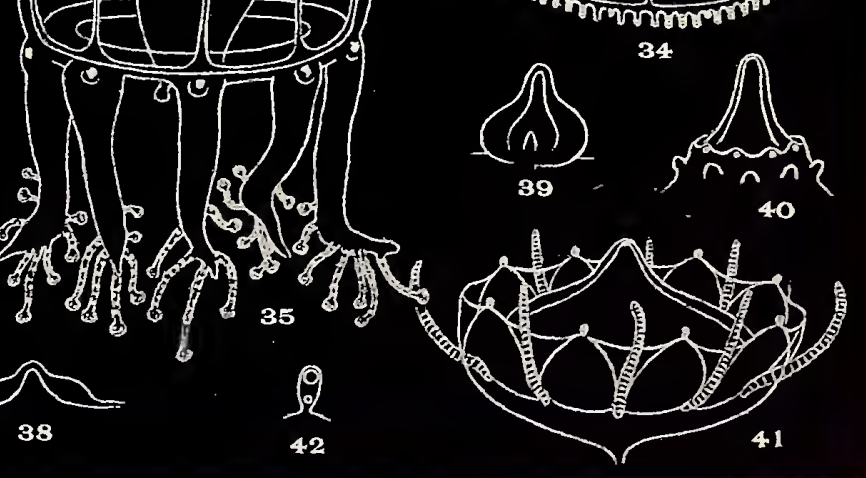


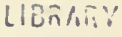

of itie

UNIVERSITY OF ILLINOIS 

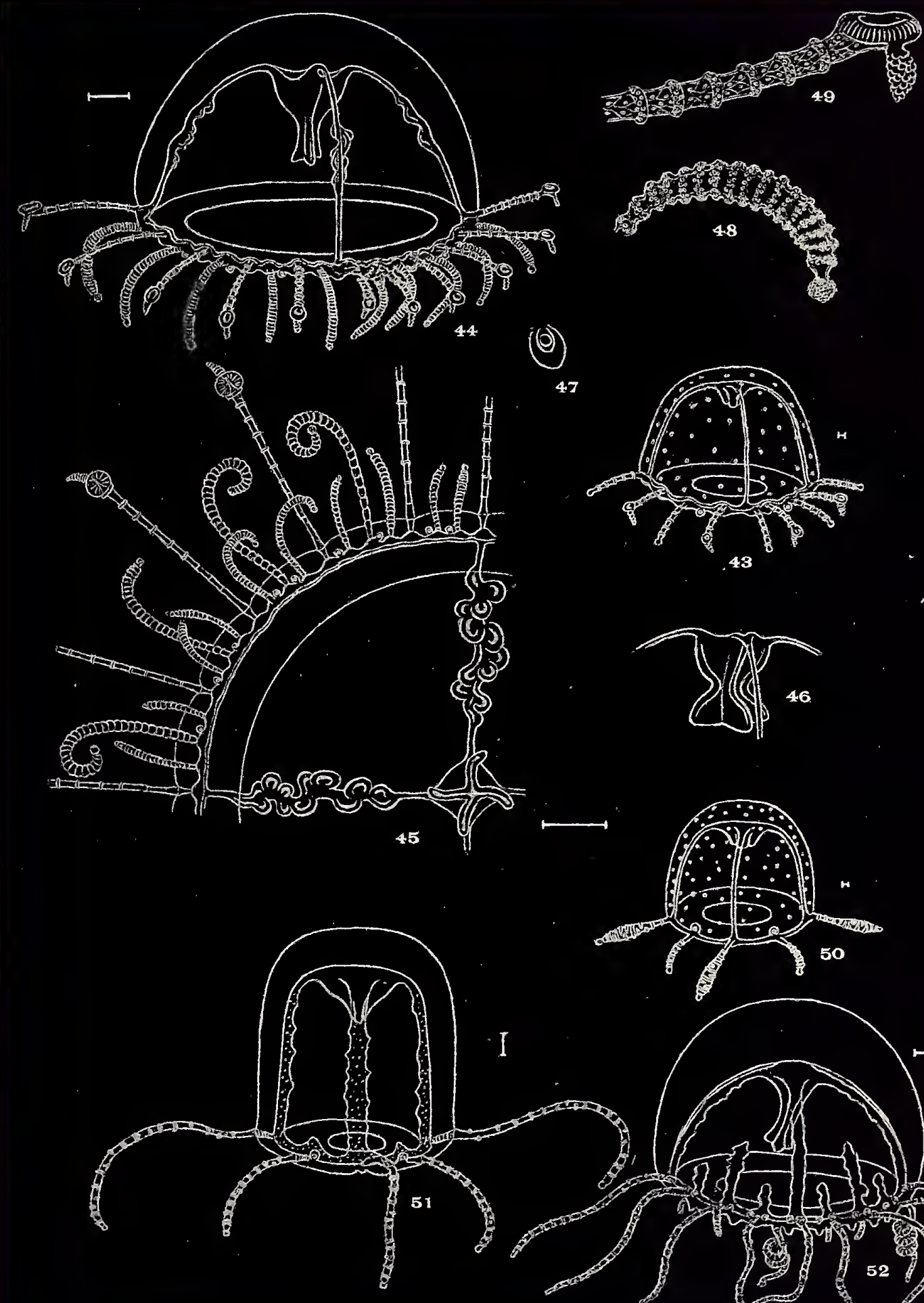
OF THE

UNIVERSITY of I!: :IN!S 
PI. VI.

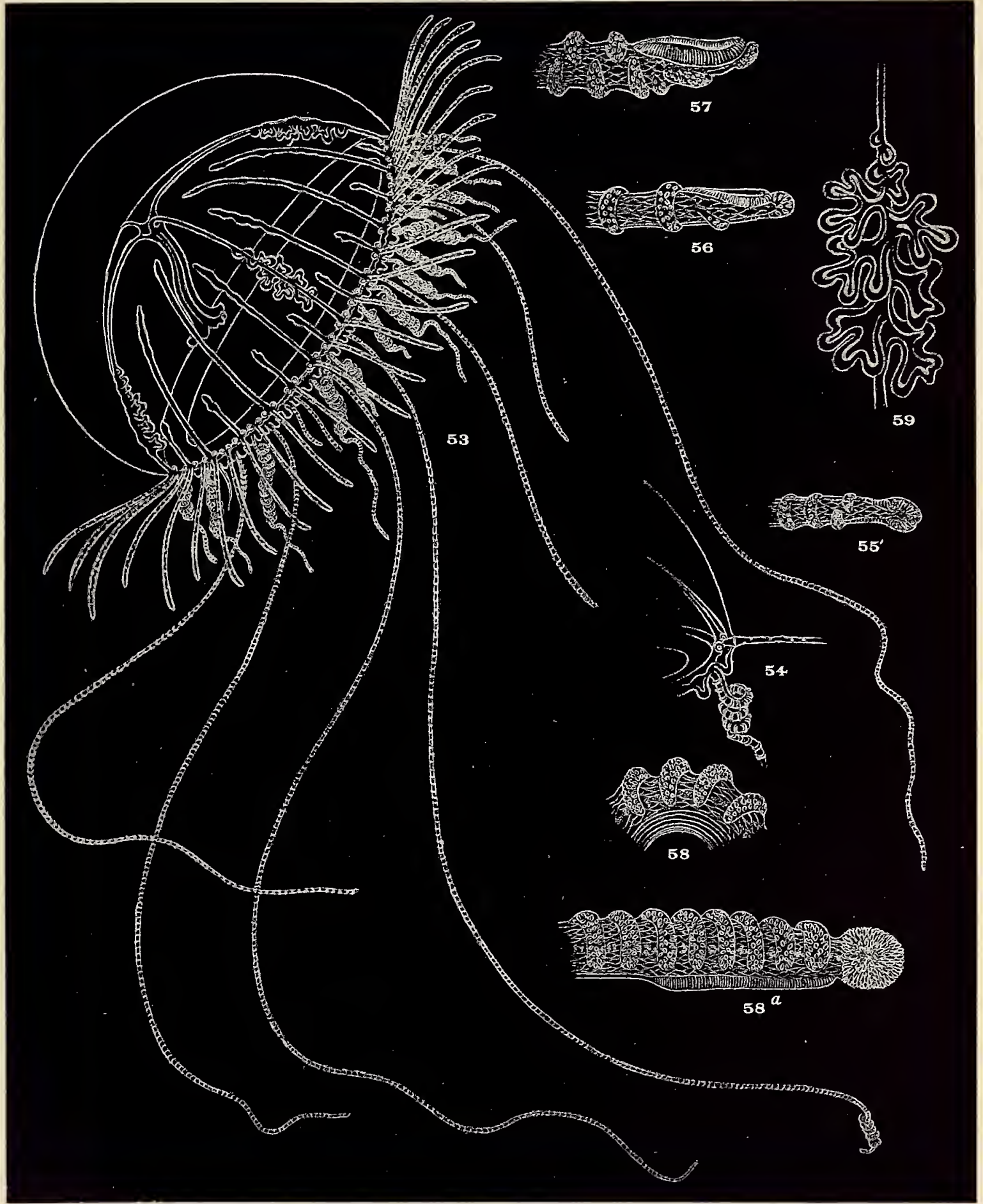

A. G. M. DEL 


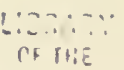

UNIVERSIIY of ILLINOIS 

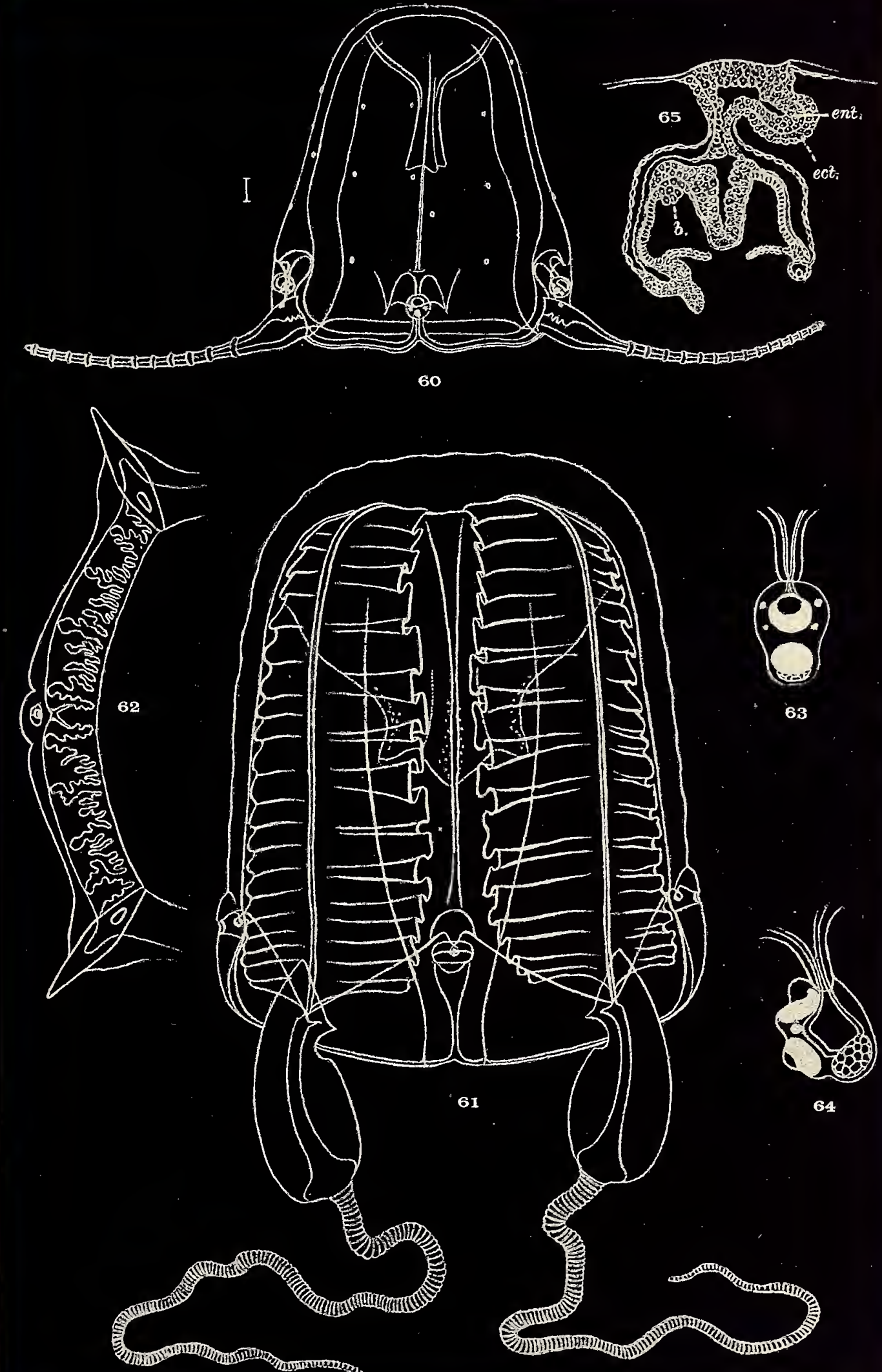
(rin

or IIIE

UNIVERSITY UT ILLINOIS 
• 




\title{
PUBLIOATIONS OF THE MUSEUM
}

\author{
OF THE
}

\section{BROOKLYN INSTITUTE OF ARTS AND SCIENCES}

These publications are issued at irregular intervals, and present the original researches of Curators and Assistants of the Museum, and work by specialists, based upon the Museum collections. Closely affiliated with these publications are those from the Marine Biological Laboratory of the Brooklyn Institute of Arts and Sciences at Cold Spring Harbor, Long Island, under the direction of Dr. Charles B. Davenport. The Museum will be pleased to exchange any or all of its publications for those of learned societies, museums or universities. Correspondence upon this subject, and exchanges may be addressed to the Curator of Books, Museum, Eastern Parkway, Brooklyn, N. Y.

Of the SCIENCE BuLLETIN, the following numbers have been issued:

Vol. I: No. 1. The Variations of a newly arisen species of Medusa, \$0.25 I: 2. Effects of Natural Selection, etc., upon Color Patterns of Lepidoptera, . . . . . . . . . . .75

I: 3. The Atlantic Palolo, ... . . . . . . . ..$_{25}$

Price per volume, $\$ 3.00$, payable in adrance.

Of the Memoirs of ART AND ARCH seloar, the following have been issued :

Vol. I: No. 1. A Renaissance Leading Façade at Gemoa, by Wm.

PRICE. H. Goodyear, . . . . . . . . . . . $\$ 0.50$

2. The Architectural Refinements of St. Marks, at

Venice, by Wm. H. Goodyear, . . . . . . 1.50

Bromide enlargements of photographs which are reproduced in these Memoirs are for sale by the Museum, and will also be exchanged for specimens in archæology, anthropology, or natural history. Communications upon this subject may be addressed to the Curstor-in-Chief, Museum, Eastern Parkway, Brooklyn, N. Y.

MEMOIRS OF NATURAL SCIENCES, Vol. I, No. 1, price $\$ 1.00$. Price per volume, $\$ 8.00$, payable in advance.

Of 'THE COLD SPRING HARBOR MONOGRAPHS, the following have been issued:

No. I. The Beach Flea; Talorchestia longicornis, by Miss Mabel Smallwood. Price, bound, 50 cents ; unbound, 40 cents.

No. II. Collembola of Cold Spring Harbor, by Charles B. Darenport. Prico, bound, 50 cents.

Pricc lists of the Soinnoe Bulletin and the Mesrorrs of ART aND ArCh KOLOGY will be provided by the Mucmillan Company, 66 Fifth Avenue, New York; and a price list of all publications may be obtained from the Ourator of Books, Musoum, Eastern Parkway, Brooklyn, N. Y. 